\title{
The decline of female circumcision in Egypt: Evidence and interpretation [Arabic]
}

Omaima El-Gibaly

Barbara L. Ibrahim

Population Council

Barbara Mensch

Population Council

Wesley H. Clark

Population Council

Follow this and additional works at: https://knowledgecommons.popcouncil.org/departments_sbsr-pgy

Part of the Demography, Population, and Ecology Commons, and the International Public Health Commons

How does access to this work benefit you? Let us know!

\section{Recommended Citation}

El-Gibaly, Omaima, Barbara L. Ibrahim, Barbara Mensch, and Wesley H. Clark. 1999. "The decline of female circumcision in Egypt: Evidence and interpretation," Policy Research Division Working Paper no. 132 [Arabic]. New York: Population Council. Version of record: https://doi.org/10.1016/ S0277-9536(01)00020-X 
قسم بحوث السياسات

\section{تراجع ختان الإناث في مصر: \\ الأدلة و التفسير}

$$
\text { بريسار بريمة الجبالي إبراهيم }
$$

الإصدار رقم 132 لسنة 1999 


\title{
تراجع ختان الإناث في مصر : \\ الأدلة والتفسير
}

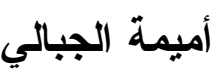 \\ بربارا إبراهيم \\ بربارا س. منش \\ ويسلي هـ. كلارك
}

أميمة الجبالي، مدرس بقسم الصحة العامة وطب المجتمع بجامعة أسيوط. بربارا إبــراهيم مسشـارك أول ومــير

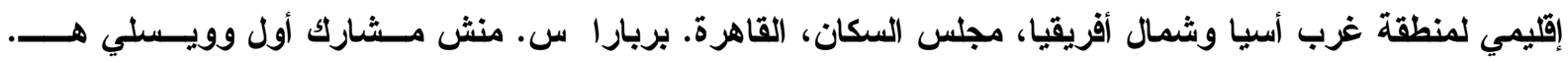
كلارك مساعد لأبحاث الفريق، قسم بحوث السياسات، مجلس السكان، نيويورك. ولقد تم تقديم إصدار مبئي من هذه الورقة في الاجتماع السنوي لاتحاد السكان الأمريكي بتاريخ 25 - 27 مارس لهابع 1999. 
ينتشر ختان الإناث في مصر • وتفيا الأبحاث بأن هذه الممارسة ماز الت مستمرة بسبب الاعتقاد بــأن

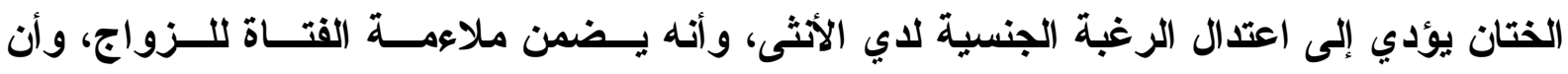

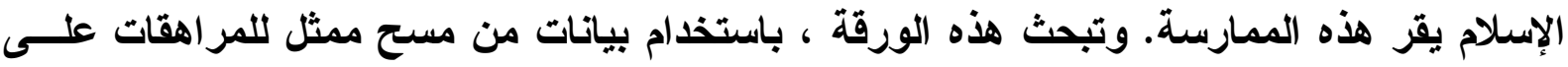
المستوى القومي ، مدى الاتتثار والمترابطات الاجتماعية للختان بين الفتيات بين سـن 10 - 19 سنة ، و الظروف المحيطة بهذه العملية واتجاهات المراهقات بخصوصها. وبينما نجد أن الأغلبيـة الاجسة العظمي من المراهقات يتم ختانهن، فإن تحليل جداول العمر يبين أن احتمالات الختان بالنسبة للفتيات

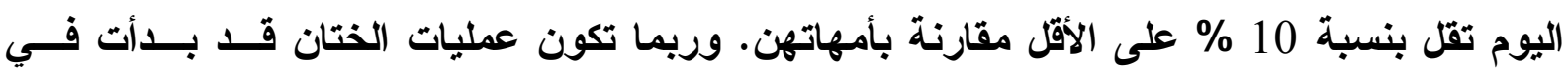
الانخفاض قبل أن يكون الفوج الحالي من الفتيات في موضع الخطر، ومع هذا فالبيانات تثثير إلـى لـى وجود ارتباط زمنى بين هذا الانخفاض وبين المؤتمر الدولي للسكان والتنمية سنة 1994 (ICPD) في القاهرة، وهو الوقت الذي أخذت فيه الحملة ضد ختان الإناث قوة دافعة. ولقد أفادت أكثــر مسن

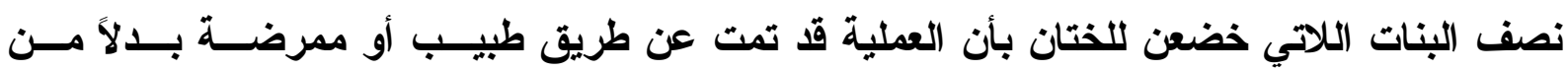
الممارس التقليدي. وهذا يمثل زيادة جوهرية في معدلات الختان التي يضفي عليها الطـابع الطبــي لئي بالمقارنة مع المجموعات السابقة من النساء المصريات. وحتى بين الفتيات اللاتي تم ختانهن، فئان تأييد هذه الممارسة ليس عاما على الإطلاق، مع وجود نسبة 14 في المائة يرون أن هذه العمليـة غير ضرورية، بينما عبرت نسبة أخرى 28 \% عن تأرجح آرائهن في ذلك الأمر ـ ولقد بين التحليل

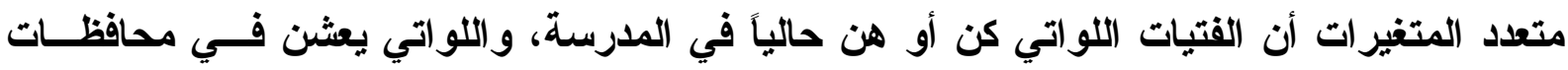

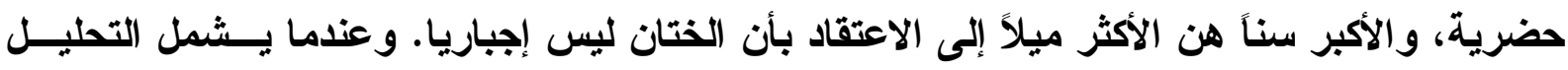
الفتيان أيضاً مع الفتيات اللواتي لم يتم ختانهن، تظهر فجوة كبيرة بين آراء الجنسين، حيث الفتيــان أكثر تأييدا لهذه الممارسة بدرجة كبيرة مقارنة بنظائر هم من الإناث.

\section{* هذه المو اد لا بحوز نقلها بدون تصريح تحريزي من المؤلفين.}

ينتشر ختان الإناث، وهو تقليد ذو جذور عميقة ومشتركة مع بلدان وادي النيل وبعـض (أجــزاء

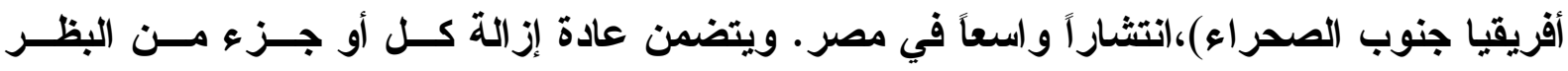
و أجزاء من الثفرين الصغيرين، غير أنه تم وصف تراوح من درجات الثدة فى قطع الأسجة عبـر البلاد. ولقد أصبحت هذه الممارسة موضع جدل كبير في مصر وفي أماكن أخرى، حيث بدأت الجهات 
الرسمية والناشطين المحليين في مجال صحة المرأة في العمل على القضاء على هذه العادة، بينمس هناك قوى أخرى أكثر تحفظاً تدافع عن هذه العادة باعتبار أنها تمثل مظهر ال للاحتثام وثقافة تقليدية.

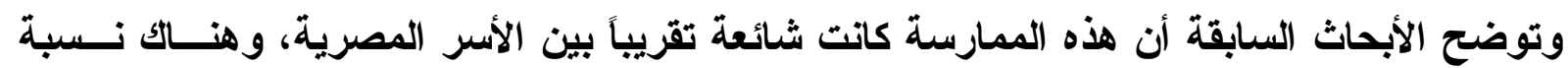
صغيرة جداً من الفئات المتعلمة وصفوة مجتمع المدن (وبعض مجموعات البدو) هي فقط التي كانت

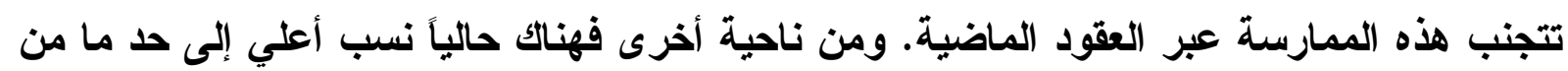
النساء يصرحن بنيتهن عدم ختان بناتهن (الزنــاتي وآخــرين El Zanaty et al E 1996 : 171).

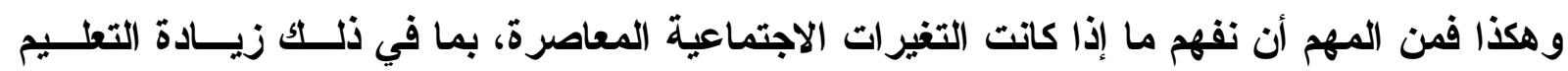
و التمدن وازدياد حدة نقاش هذا الموضوع في المجتمع تؤثر على ممارسة ختان الإناث. علي مدى هذه الورقة فإننا نستخدم مصطلح ختان الإناث، وهو ترجمة لأحد المصطلحات العربية في

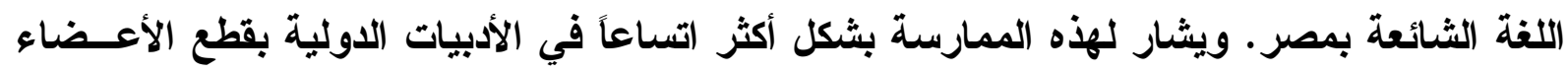

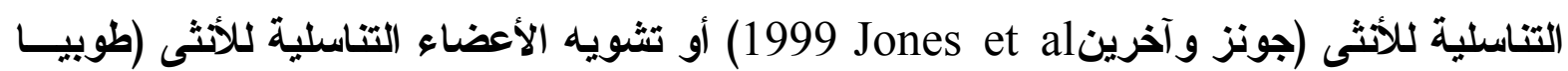
1995Toubia

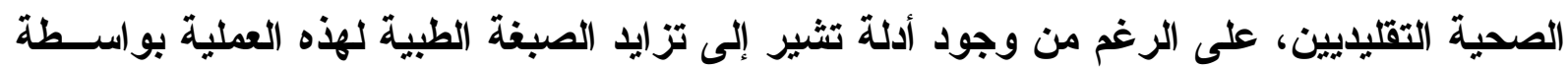

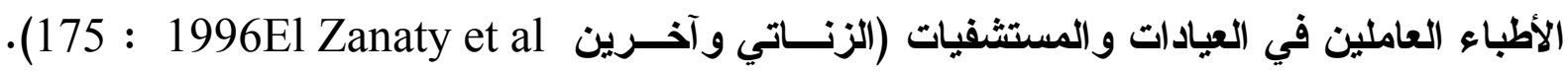
ويتم ختان الإناث عادة قبل سن البلوغ أو عند بلوغ الفتاة مباشرة، وكثير الما يكون ذلك مع إجـراء

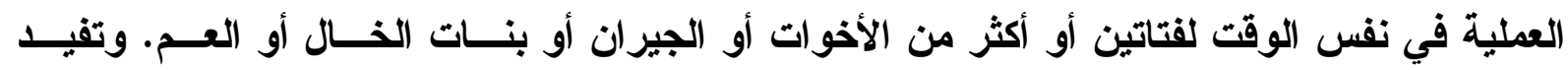

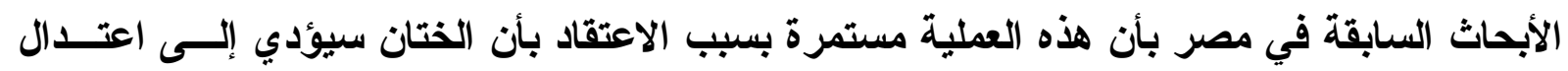

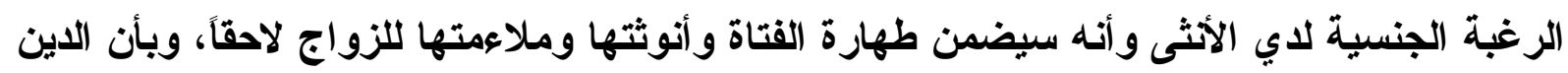

$$
\text { يقر الختان (أسعد Assaad } 1980 \text { : 5). }
$$

بدأت في الخمسينيات مناقثنات متفرقة بين المجتمعات الطبية والمنظمات غير الحكومية المـصرية حول مدى مناسبة ختان الإناث. وصدر قرار لوزير الصحة سنة 1959 يحظر عـــى العـاملين فــي المهن الطبية إجراء عمليات ختان الإناث بدون دواعى طية واضحة (طوبيا Toubia 1998 : 56).

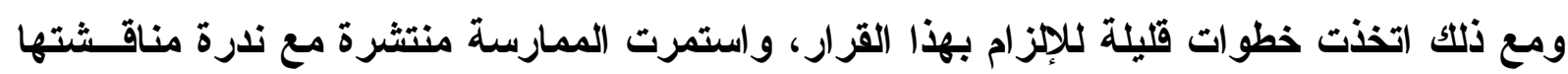
على المستوى العام. 
وعبر العقود الثلاثة التالية عمل عدد صغير من المجموعات المدافعة عن صحة المرأة محلياً علىى

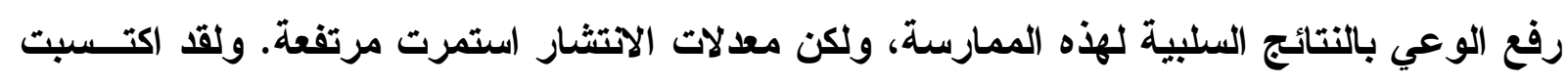

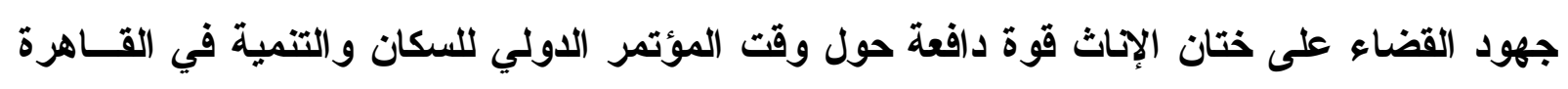
سنة 1994. ولقد عرض تقرير إخباري لقتاة CNN حالة فتاة مصرية تبلغ من العمر 13 سنة أثناء

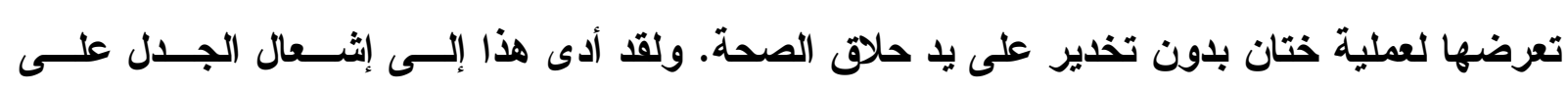

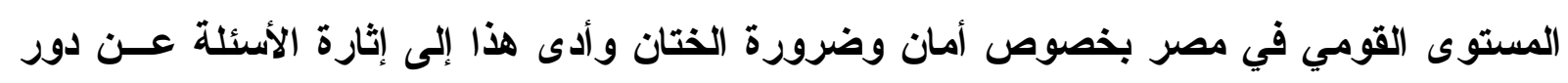
الهيئات غير المصرية في هذه المسألة القومية الحساسة. ولقد حاول وزير الصحة حينئذ تقويض دور الممارسين التقليدين فى ختان الإثاث بإصدار قرار فــي

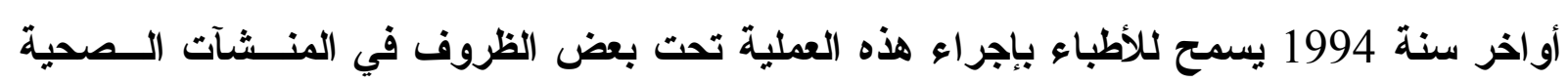

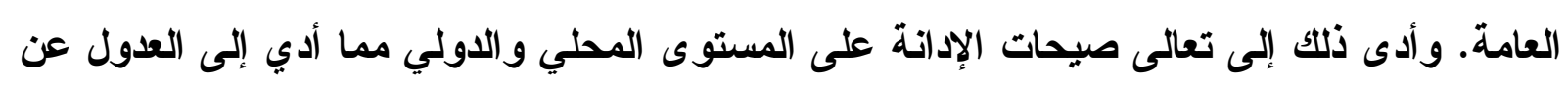

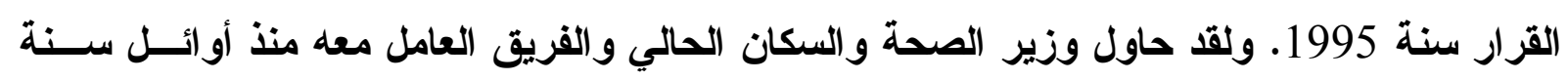
1996 الحد من هذه الممارسة على الرغم من الهجوم من الجهات المحافظة والتقليدية في وسـائل

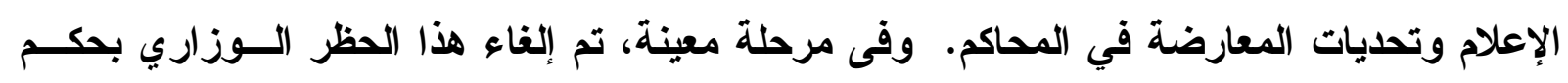

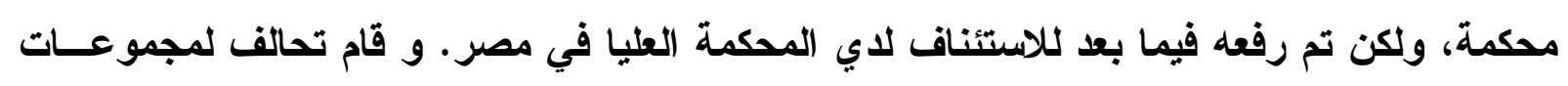
مدنية منذ سنة 1994 بالعمل نحو القضاء على ظاهرة ختان الإحاث في أنحاء مصر من خلال تعلــيم

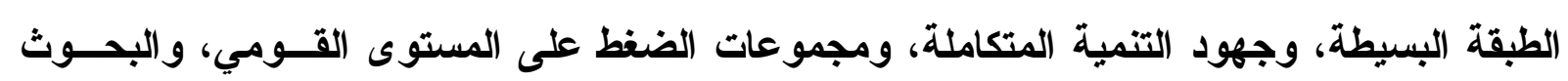
2 NCPD)

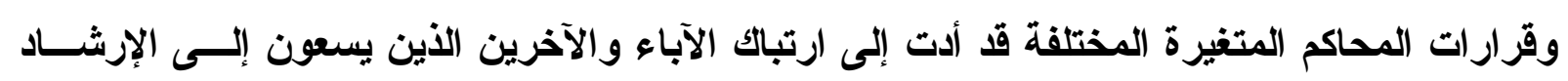
بخصوص الاستمرار في هذه الممارسة مع بناتهم.

\section{الاتتثار الاجتماعي للسلوك الجديد.}

أظهر المسح الصحي والديموجرافي في مصر لسنة 1995 (DHS) أن معدل الانتشار العام لظــاهرة

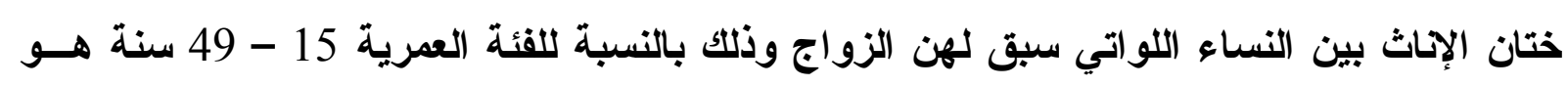

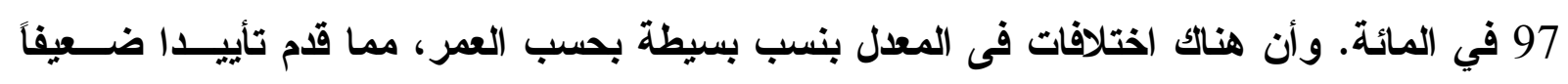

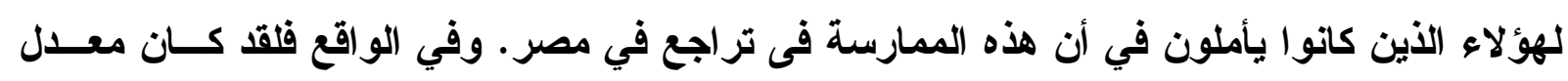

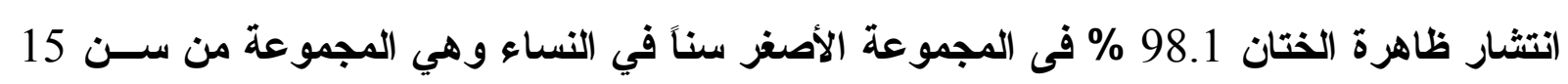


إلى 19. ولكن كان هناتك ارتباطاً سلبياً بين الختان والتعليم والإقامة بالمناطق الحضرية. وبالإضــافة

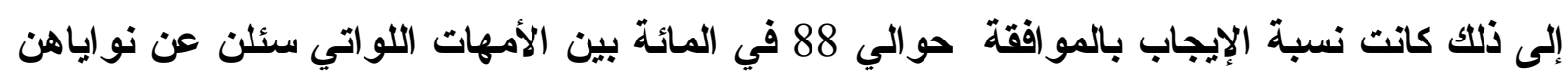
بخصوص ختان بناتهن. ونظراً لأن جميع النساء في مسح DHS و المسوح المماثلة كن متزوجــات

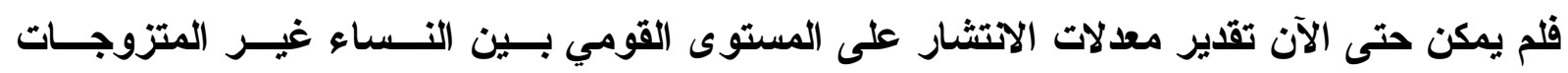
وبصفة خاصة البنات الأصغر سناً والذى يعكس سلوكهن الاتجاهات الناثئة في المجتمع. وبصفة خاصة لم تكن لاينا معلومات بخصوص جموع الفتيات بعد مؤتمر السكان ICPD التي دخلت

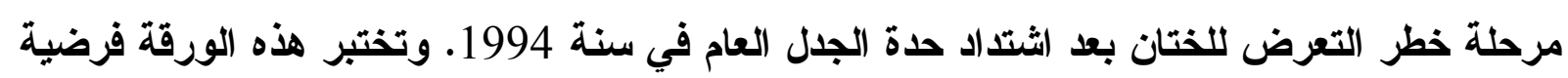

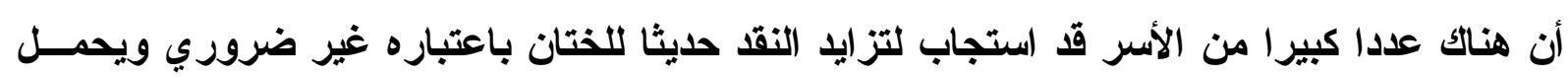

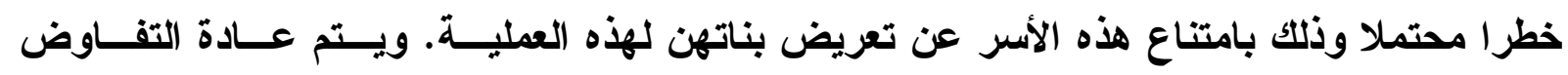

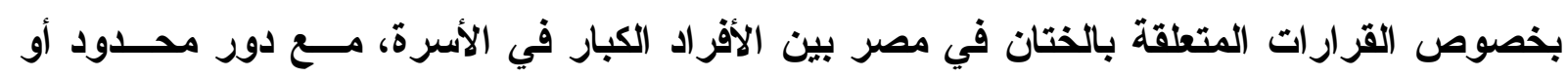

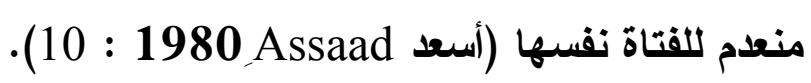

ويمكن تفسير العملية التى تقوم من خلالها بعض العائلات بتعديل وجهات نظرها التقليدية ومن ثــــ

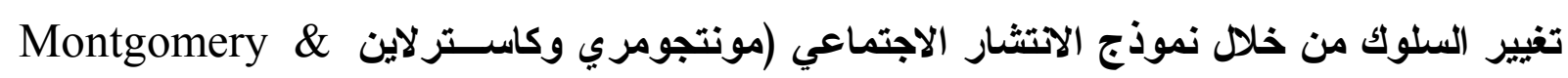
1996 Casterline

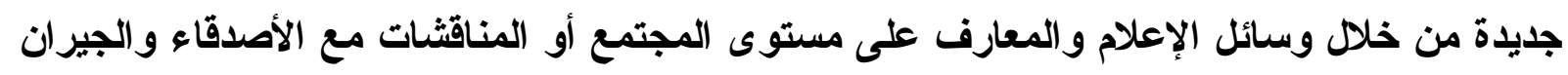

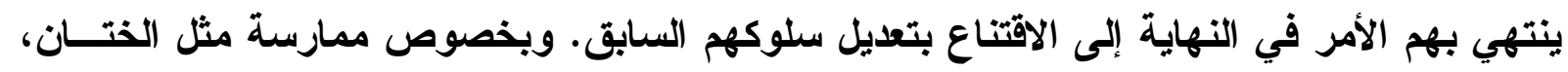

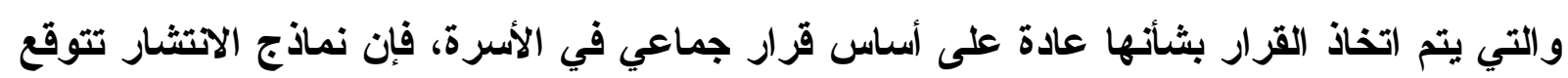

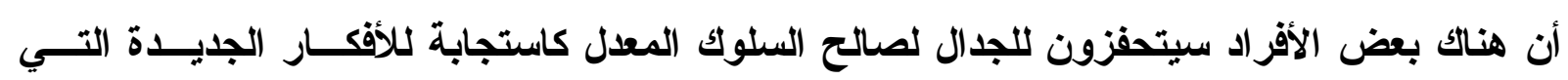

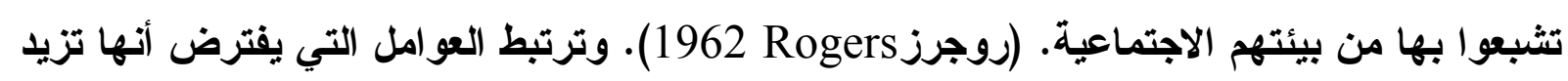

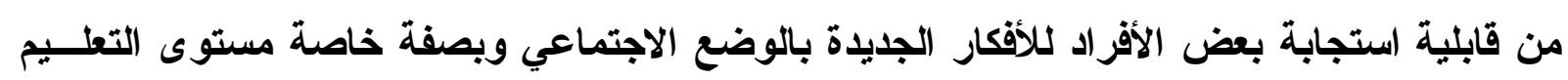

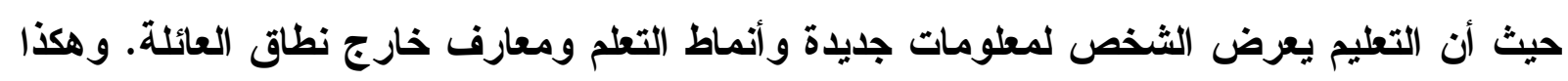

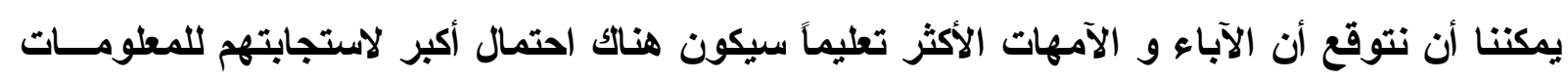
الجديدة و النقاش بأن يقرروا عدم ختان بناتهم. وبنفس الأسلوب فإن المجتمعات التي تقدم فرصة أكبر للوصول للأفكار الجديدة سواء كان ذلك مسن

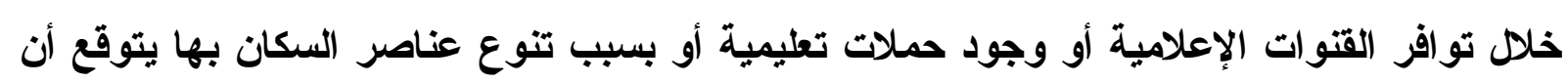


تتضمن نسباً أعلي من الأفراد الذين يعلون كل من الاتجاهات والسلوك. وهـــا يــؤدي بنــا إلــى الافتراض بأن الإقامة بالمناطق الحضرية في مصر ستكون مرتبطة بنسب أعلي ممن يتذذون القرار بعدم الختان.

مصدر البيانات

أصبحت بيانات مسح الآسر المعيشية الممثلة على المستوى القومي متوافرة لأول مرة في مسصر

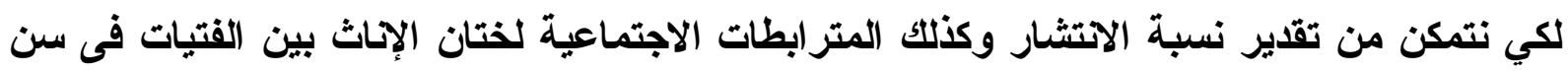
10 إلى 19 سنة حالياً. ومن خلال مسح مرحلة المراهقة والتغير الاجتماعي فــي مسـر (ASCE) و الذي تم إجراؤه في سنة 1997، تم الحصول على معلومات عن الختان من خلا عينة عـشـوائية

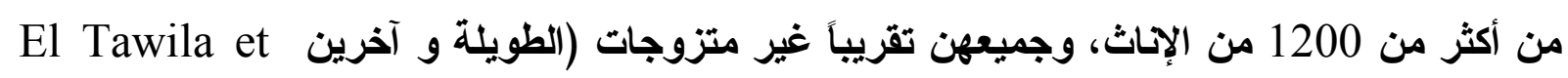

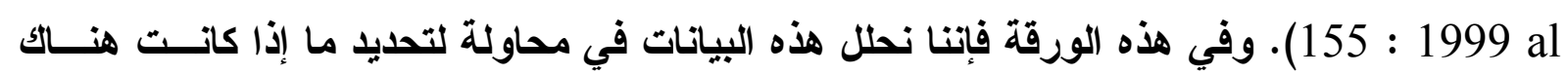

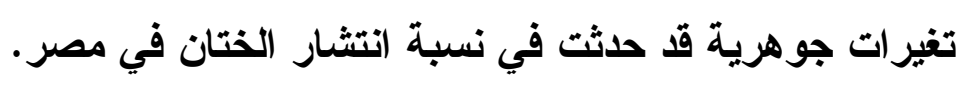

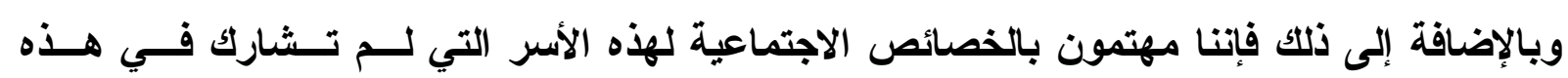

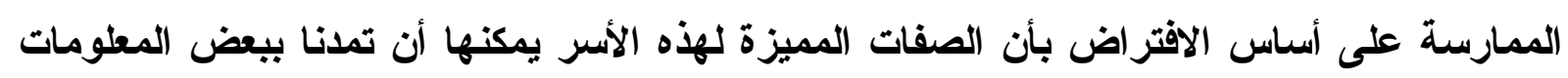

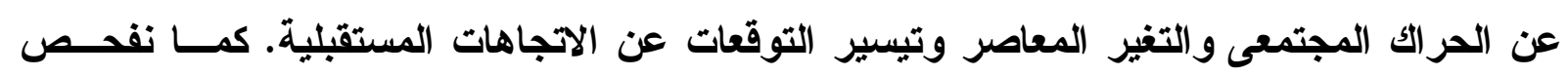
أيضاً الأحوال المحيطة بعملية الختان مثل عمر الفتاة، ومكان إجراء العملية ومن يقوم بها. وأخيـراً

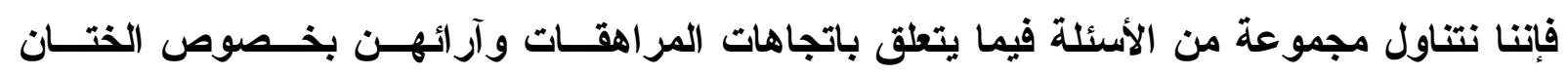
ومعتقداتهن بخصوص أهمية الختان للزواج.

إن مسح مرحلة المراهقة والتغير الاجتماعي في مصر ASCEدراسة لعينة ممثلة علـى المستوى القومى، احتمالية، متعـددة المراحـل Nationally Representative, multistage propability

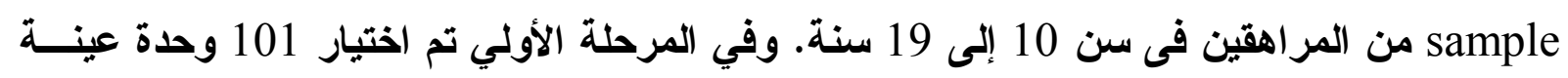

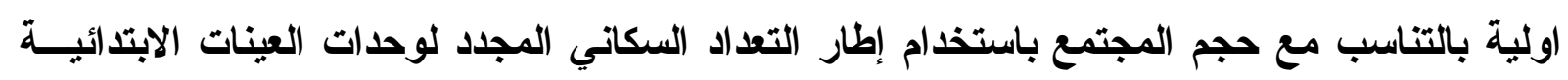

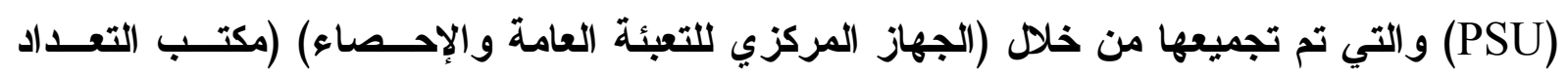
السكاني المصري). ولقد تم استبعاد محافظات الحدود الخمس فقط حيث يعيش بها نـسبة 1.5 \% 1.5 تقريباً من سكان البلاد. 
وتم بعد ذلك تلدريج وحات العينات الآولية وفقال ل 21 محافظة و أيضاً بحسب الإقامة فـــ المنــاطق

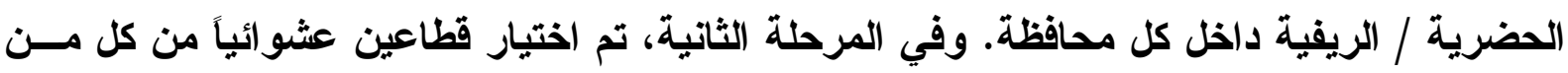
الوحدات الإبتدائية للعينات (101 وحدة) بعد عملية تجزئة / أو تقسيم تمت على أساس نتائج عملية عد سريع في كل وحدة من وحدات العينات الآولية PSU. ولقد تفاوت حجم القطاعات بين الوحدات المختلفة للعينات الآولية PSU بغرض العصول على عينة متوازنة تلقائيــا (self-weightedمـن

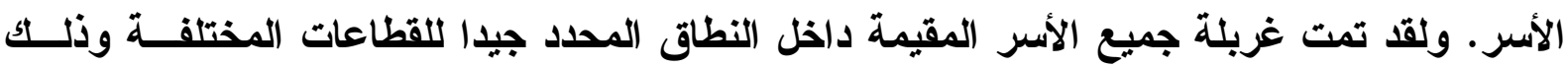
باستخدام قائمة لقيد المطومات الخاصة بالأسرة بخصوص التركيبة العمرية - الجنسية لأفر اد الأسرة

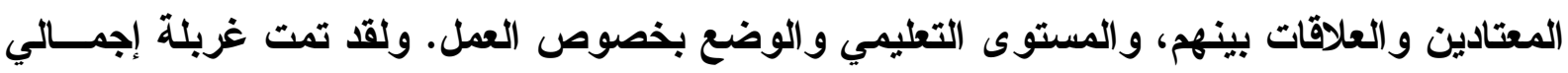
13.271 أسرة بنجاح في هذه المرحلة من المسح. تم بعد ذلك تحديد الأسر المؤهلة للاراسة باعتبارها الآسر التي تضم عضوا واحدا على الأقـل فـــي مرحلة العمرية 10 - 19 سنة، وتم اختيار مراهق واحد من كل من الجنسين فى هذه الفئة العمرية

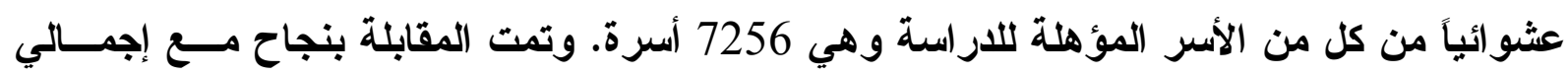
9128 من المراهقين (4354 أولاد و 4774 بنات)(1). وكان عدد الحالات (ولد وبنت) مسن نفس هـس الأسرة والتي تمت مقابلتها بنجاح 2554 حالة. وكانت جميع الحالات التي تم اختيارها عشو ائياً من

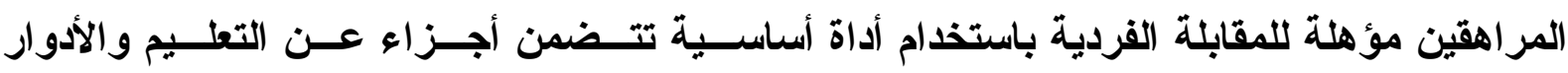
الاقتصادية و الصحة و الصفات الثخصية والأشطة خلا اليوم السابق للمقابلة.

و هكذا فلقد كان هلف المسح القومى عن المراهقة والتغير الاجتماعى في مصر ASCE هو وضـــع توصيف شامل للجو انب الهامة في حياة المراهق في مصر . ولقد تم توجيه السؤال أيضاً لربع العينة

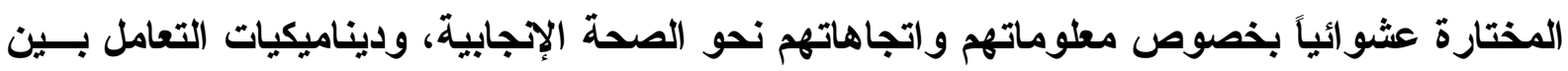

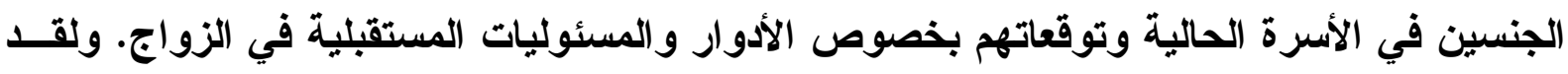

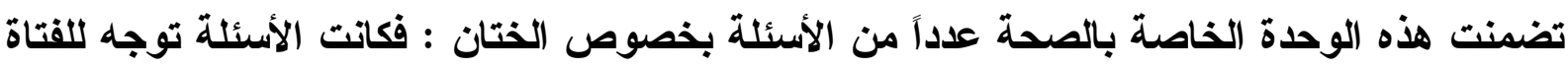

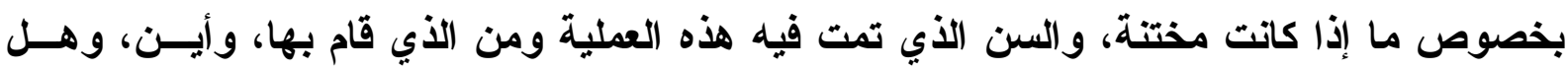

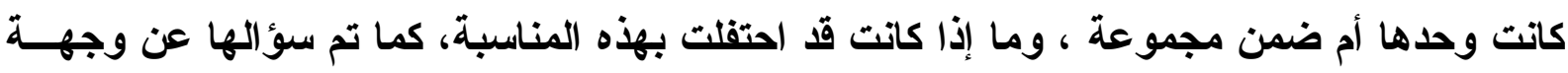
نظرها عن الختان وهل هو ضروري ولماذا. و تم توجيه سؤال أخير لكل من الأولاد والبنات من سن 16 إلى 19 سنة عن وجهة نظرهم بخصوص ما إذا كان الختان ضرورياً للمر أة قبل الزواج. 
يبين الثكل 1 احتمال تعرض الفتاة المراهقة في مصر للختان في سن معينة(2). ونظراً لأن خبـرة

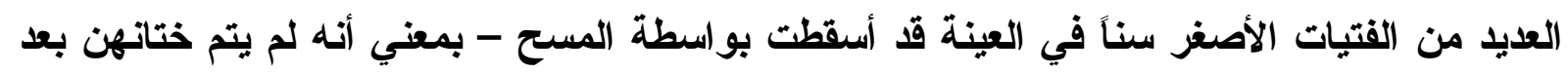

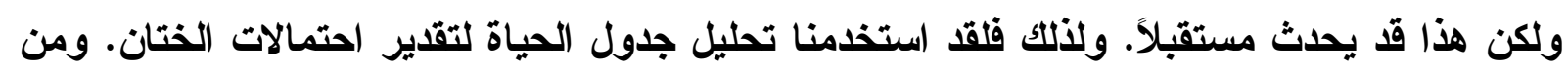

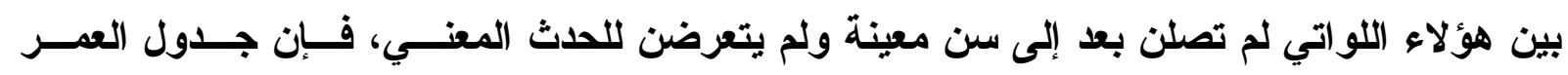

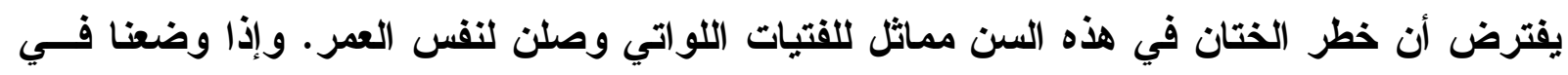
الاعتبار أن هذا الافتراض صحيح، ففي هذه الحالة كما هو مبين في الشكل 1، هناك نسبة 84.2 \% تقريباً من البنات في مصر سيتم ختانهن. وهذه النسبة أقل بكثير من نسبة 97 في المائة المسكجلة هينة في المسح الديموجر افى والصحي لسنة 1995 للنساء اللواتي سبق لهن الزواج من فئة العمر 15 49، ونسبة 98.1 في المائة التي تم تسجيلها للنساء اللواتي سبق لهن الزواج في المرحلة العمرية

$$
15 \text { - } 19 \text { سنة في نفس المسح. }
$$

وتعطى بيانات المسح الديموجرافى والصحي DHS الانطباع بأن انتشار الختان لم يتغير في السنوات الأخيرة، ولكن نظراً لأن عينة المسح الديموجرافى والصحي DHS تتكون فقط من النساء اللــواتي سبق لهن الزواج، ونظراً لارتفاع العمر عند الزواج (الزناتي وآخرين (El Zanaty et al)- 1996)

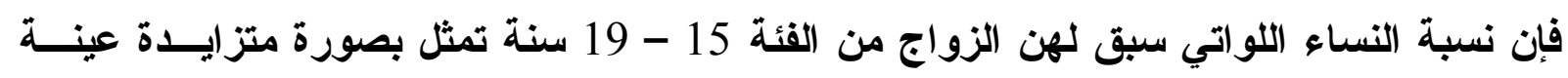

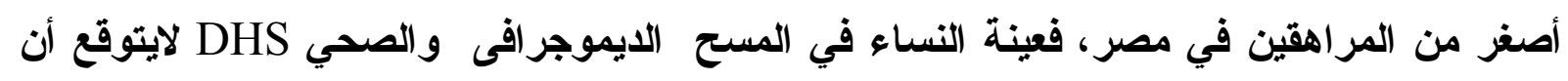
تكثف أي تغير ات قد تكون حدثت مؤخراً. وطبقاً لبيانات الأسر في المسح الـــيموجر افى والــصحي DHS فأن هناك نسبة أقل من 15 في المائة من النساء المصريات فى سن 15 - 19 متزوجــات. و الفتيات اللاتي يتزوجن قبل سن 20 هن الأكثر فقراً و الأقل تعليماً عن أغلبية المراهقات المصريات.

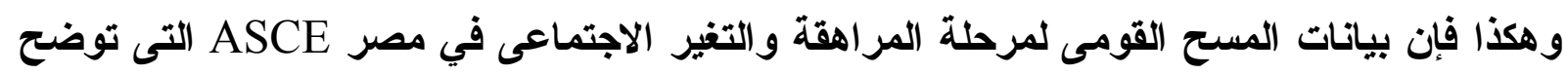

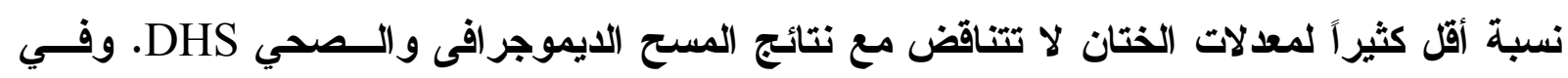
الواقع فإنه من بين النساء المتزوجات في عينة المراهقات، فهناك نسبة 97.8 في المائة تم ختانهن،

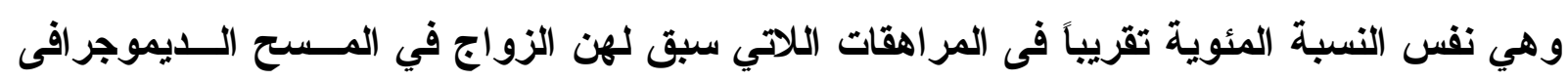

والصحي DHS. (3) ونسي 


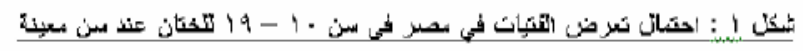

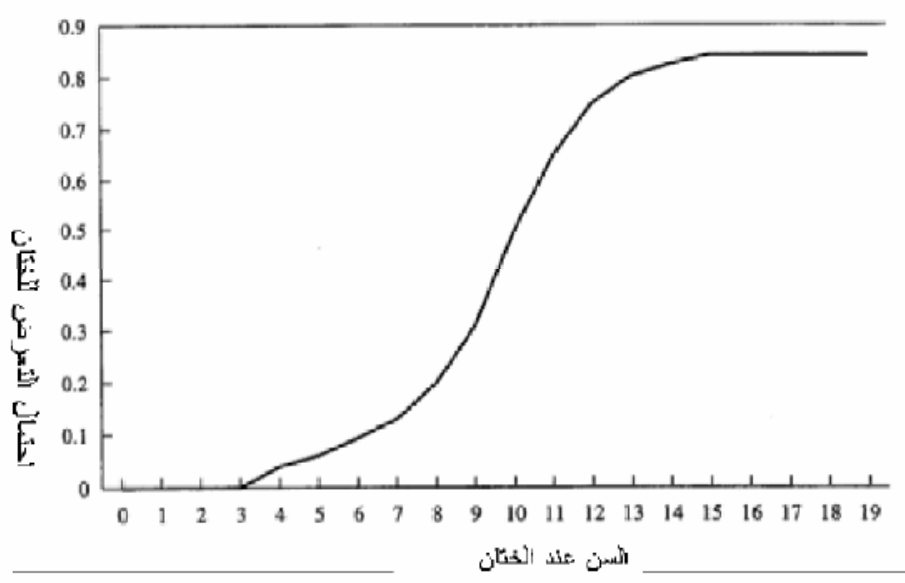

شكل 1 : احتمال تعرض الفتبات في مصر فحى سن 10 - 19 للختان عند سن معينة 
11

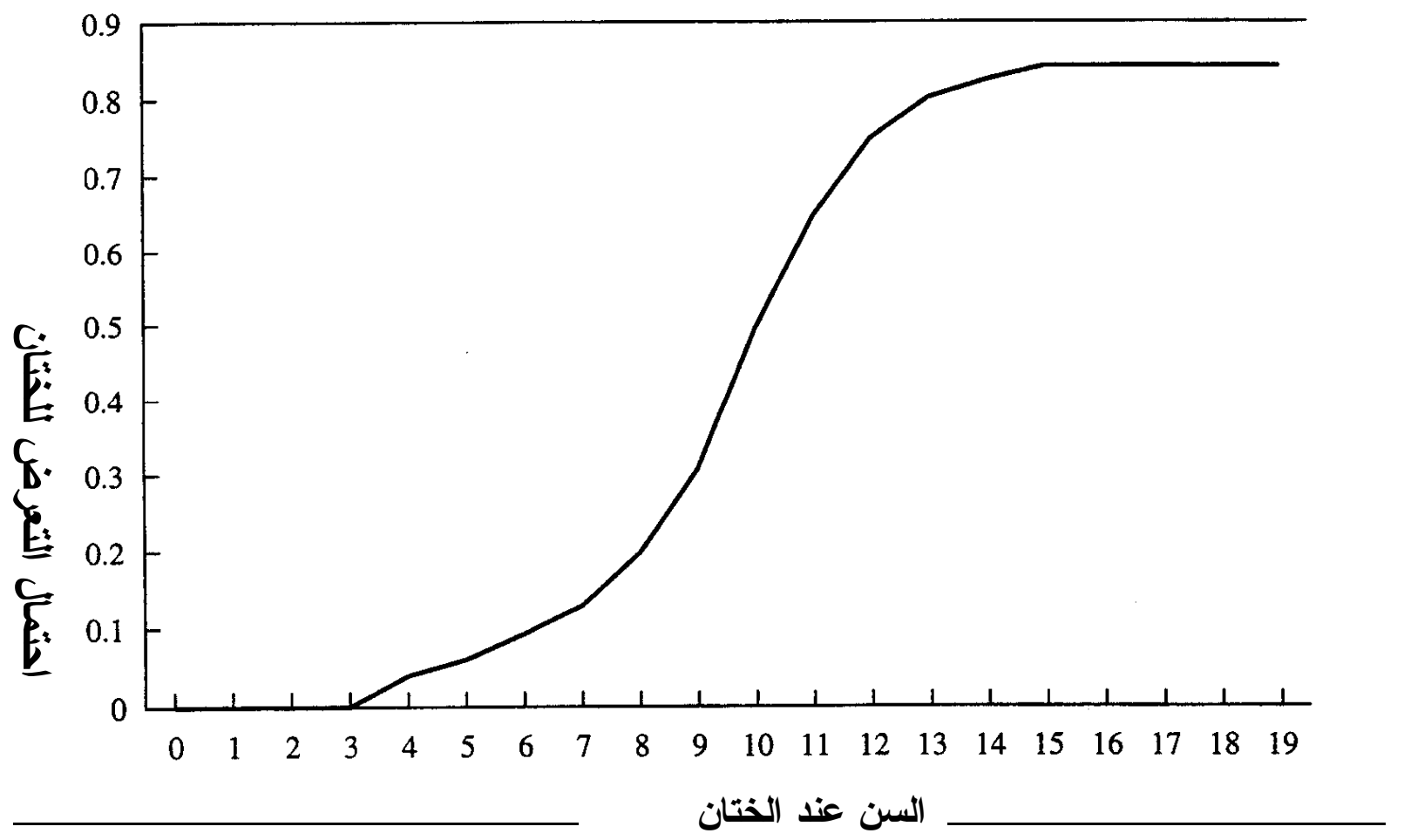


شكل 2 : احتمال تعرض الفتبات في مصر فى سن 10 - 19 للنتان عنــــــن معنــة، بحسب المجموعة العمرية الحالبة.

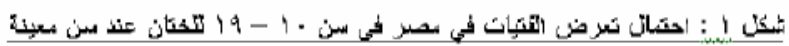

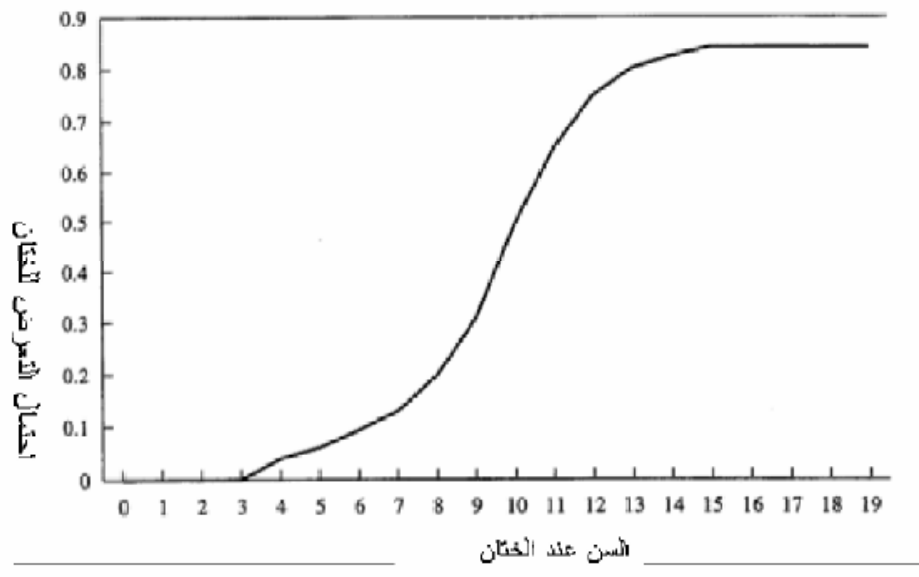




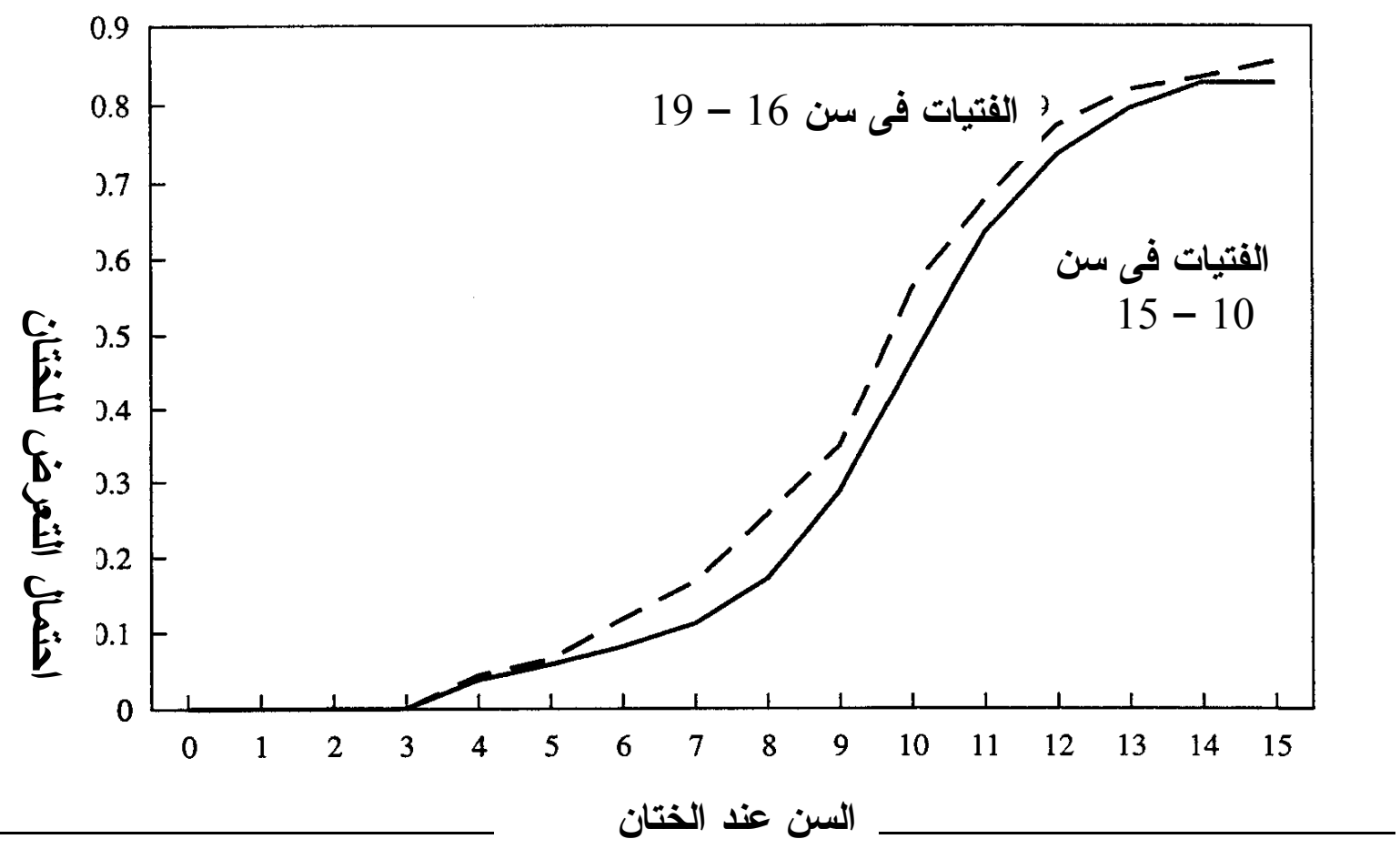

الأدلة الإضافية على حدوث تراجع في معدلات الختان

بمقارنة بيانات مسح المراهقة والتغير الاجتماعى في مصر ASCE عن الختان مع بيانات المسـح

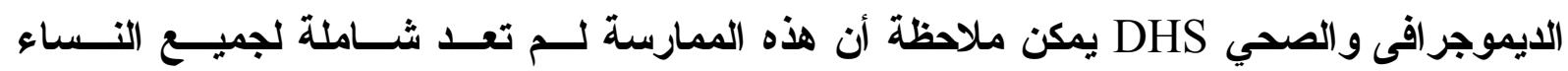
المصريات. وبالإضافة إلى ذلك يمكنتا أن نرى الأدلة التي تدل على هذا التراجع في بيانسـات مسكسح المراهقة والتغير الاجتماعى في مصر ASCE نفسها. و الثكل 2 يبين احتمال تعرض الفتاة المراهقة في مصر للختان بشكل منفصل بالنسبة لكل من الفئة العمرية 10 - 15 سنة والفئة العمريــة 16 19 سنة لكل منهما. وهنا حيث أننا قد قمنا بإنثاء جدولى حياة، فإن الحد العمري الأعلى هــو 15

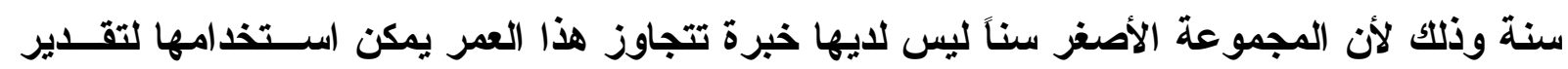
احتمال حدوث هذا الحدث. و كما يمكنتا أن نرى فإن احتمال الختان أقل بين الفتيات فى ســن 10 15 سنة مقارنة بالفتيات فى سن 16 - 19 سنة. وبينما نجد أن هذا الفرق صغير، فإن التناقص في

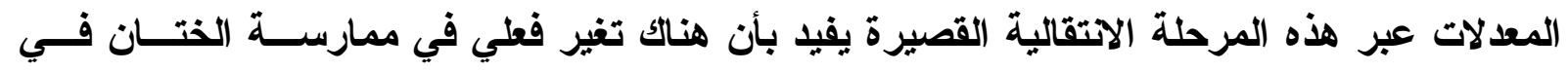

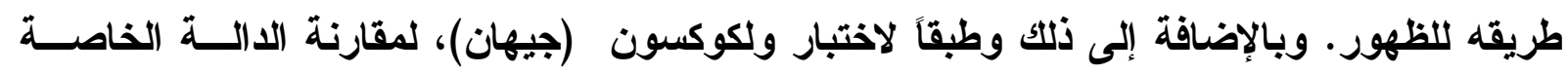


بالاستمرارية فى الحياة لمجموعتي فئات العمر عثد كل مدة أو عمر، فإن الفرق في هذه الحالة بعتبر معنوياً عند القيمة P أقل من 0.001.

و السؤال الذي من الطبيعى أن يظهر هو ما إذا كان النقاش على المستوى القومى عن أمان وضرورة

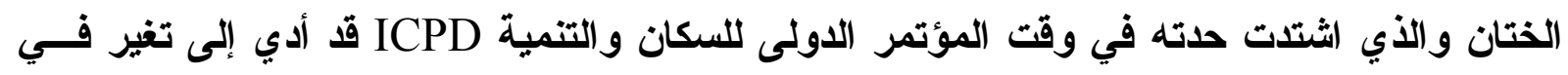
السلوك. وهناك طريقة لاستكثاف هذا السؤال بمقارنة المجموعات العمرية التي كانت أكثر تعرضاء

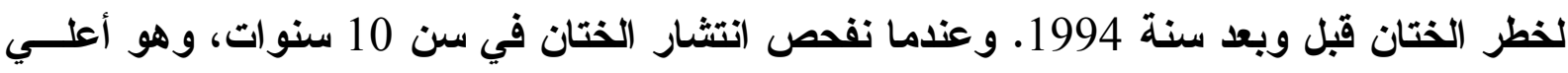

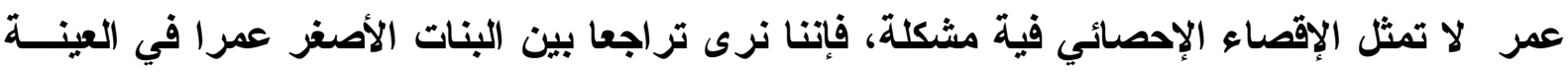

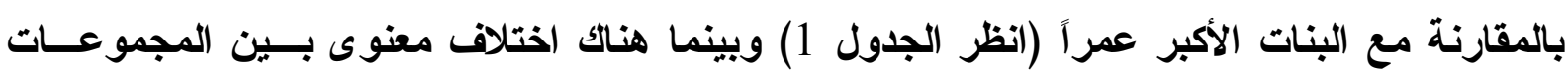

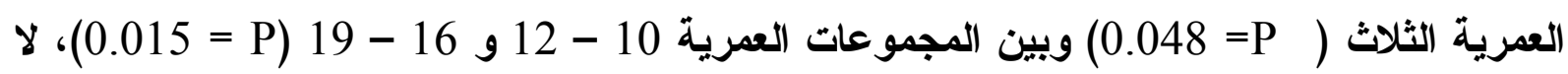
يوجد اختلاف معنوى بين الفئة 10 - 12 سنة والفئة 13 - 15 سنة أو بين الفئة 13 - 15 و الفئة

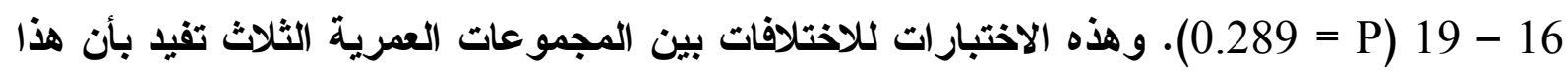
التراجع قد تسارع بعد المؤتمر الدولى للسكان والتنمية ICPD. وقد ولات البنات في العينة من فئة العئة

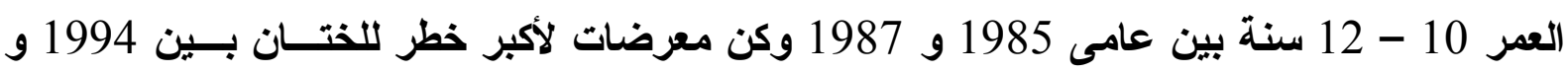
1997 بينما كانت البنات فى سن 16 - 19 معرضات لأكبر خطر بين عامى 1987 و 1991. ومن المحتمل أن يكون التراجع في الختان والذي كثفت عنه بيانتا قياسا مصطنعا بسبب الزيـادة

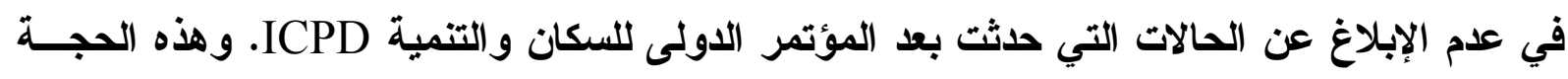

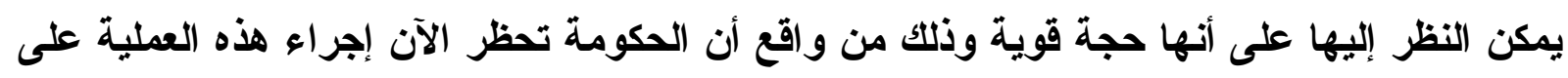
جميع الممارسين المرخص لهم. وهذا الحظر يمكن تفسيره على أنه رسالة سلبية قوية بثأن ملاعمة الفية

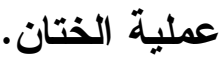

وفي الحقيقة فإن الأدلة الدتو افرة لا تؤيد التفسير المبني على أساس نقص الإبلاغ عسن الحسالات.

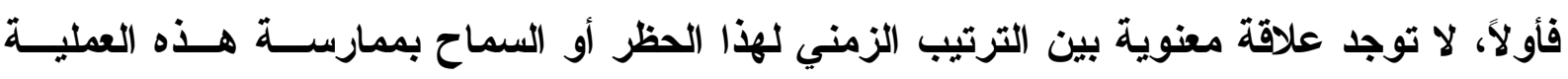

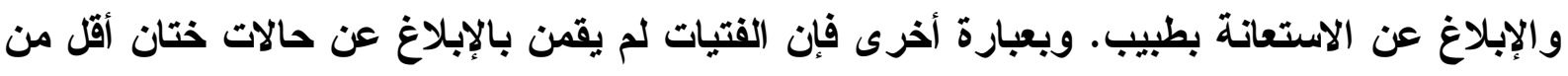

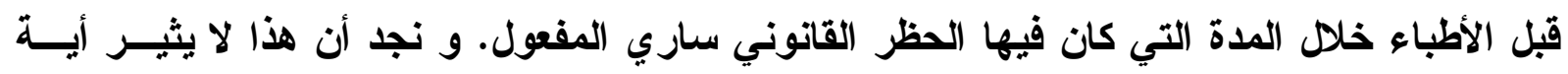
دهثة، إذا وضعنا في الاعتبار عدم الوضوح بصفة عامة للموقت القانوني من الختان عبر المراحل 
المختلفة. وبالتقلبات المتعددة التي حدثت في القانون، فإن الآباء (ويناتهم) كان الأرجح أن يـشعروا بالارتباك بلاً من الثعور بالخوف بسبب ما يعرفونه عن الموقف القانوني من هذه العملية.

جدول 1 : النسبة المئوية للفتيات المصريات اللاتي تم ختانهن في سن 10 طبقاً لعمر الفتاة في وقت

(المسح (أ). (المول

\begin{tabular}{|r|r|r|}
\hline N العمر عند المسح المئوية التي تم ختانها حتى سن 10 \\
\hline 402 & 27.4 & $12-10$ \\
\hline 356 & 30.3 & $15-13$ \\
\hline 425 & 35.2 & $19-16$ \\
\hline 1182 & 31.1 & الإجمالي \\
\hline
\end{tabular}

أ - البيانات تمت موازنتها.

ملاحظة: الفروق بين الفئات معنوية عند

ثانياً، فإن تناقص معدلات الختان طبقاً للمسح أكبر بين الفتيات الأصغر عمراً في العينة. فلو كانــــ

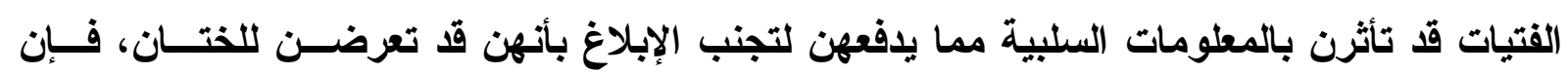

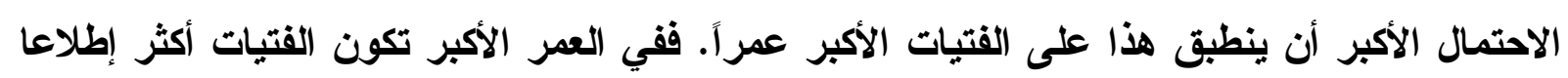

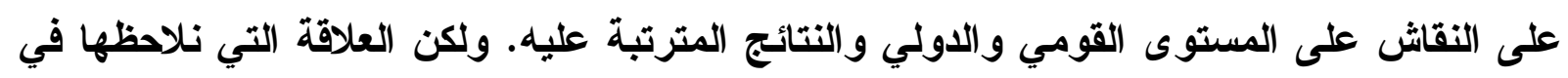

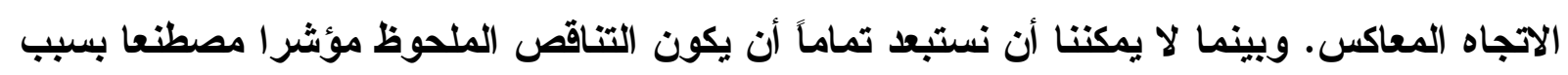

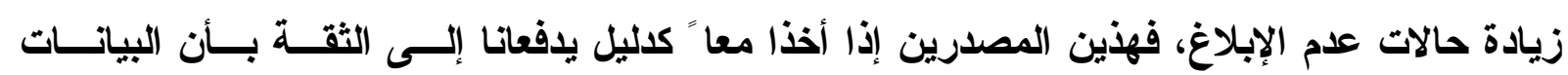

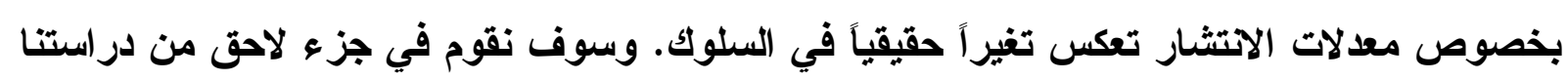
التحليلية باختبار واضح لتنأثير المؤتمر الدولى للسكان و التنمية ICPD.

العمر عند الختان

قبل أن يمكتنا الاستنتاج بأن هناك تراجعا لختان قد حدث في السنوات عندما كاتت الفتيات في عيــــة

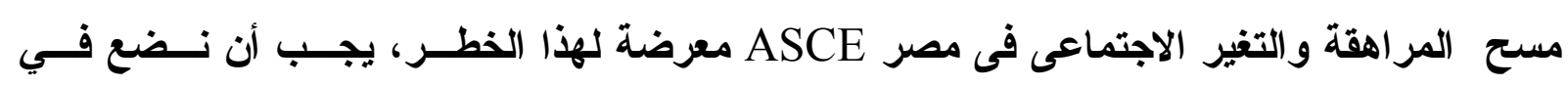
الاعتبار احتمال أن الفتيات الآن يتعرضن لهذه العملية فى سن أكبر. والثكل 3 يبين رســــاً بيانيـاً لمعدل الخطر حسب العمر • و معدل الخطر هو تقدير لاحتمال أن الفتاة التي بقيت حتى بداية المرحلة

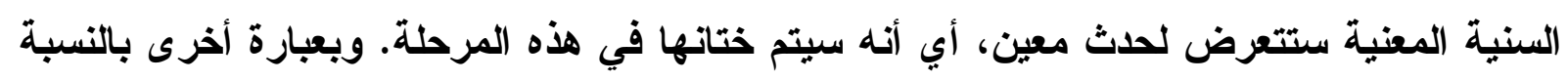


ختان الفتاة حتى بلوغها سن الستة عشر، فإن البيانات تفيد بأنها غير محتمل ختانها. وبالإضافة إلى

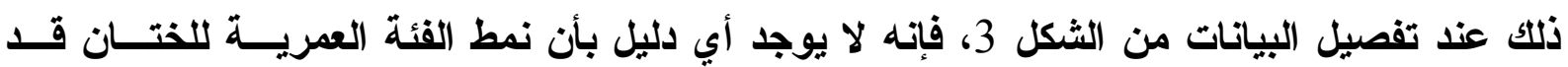
تعرض للإزاحة بحيث تكون خطر الختان بين الفتيات الأصغر عمراً أعلي بصفة ثابتة عند الأعمـار الأكبر (الثكل 4). وبعبارة أخرى لا يوجد دليل على أن السن عند الختان قد حدثت له زيادة جوهرية

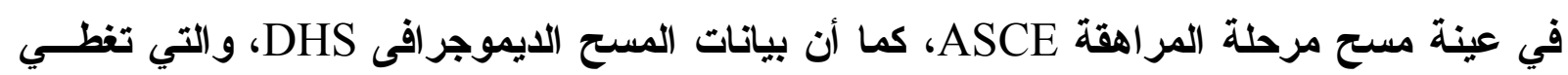
فئات عمرية أكبر، تبين أن العمر عند الختان لم يتغير مع مرور الوقت. والعمر الوسيط عند الختان ماز ال كما هو بالنسبة للنساء اللواتي سبق لهن الزواج من فئات العمر 15 - 49 سنة تماماً كما هو بالنسبة لبنات هؤلاء النساء.

شكل 4 : معدلات خطر الختان للفتيات المصريات عند كل سن، بحسب المجموعة العمرية الحالية.

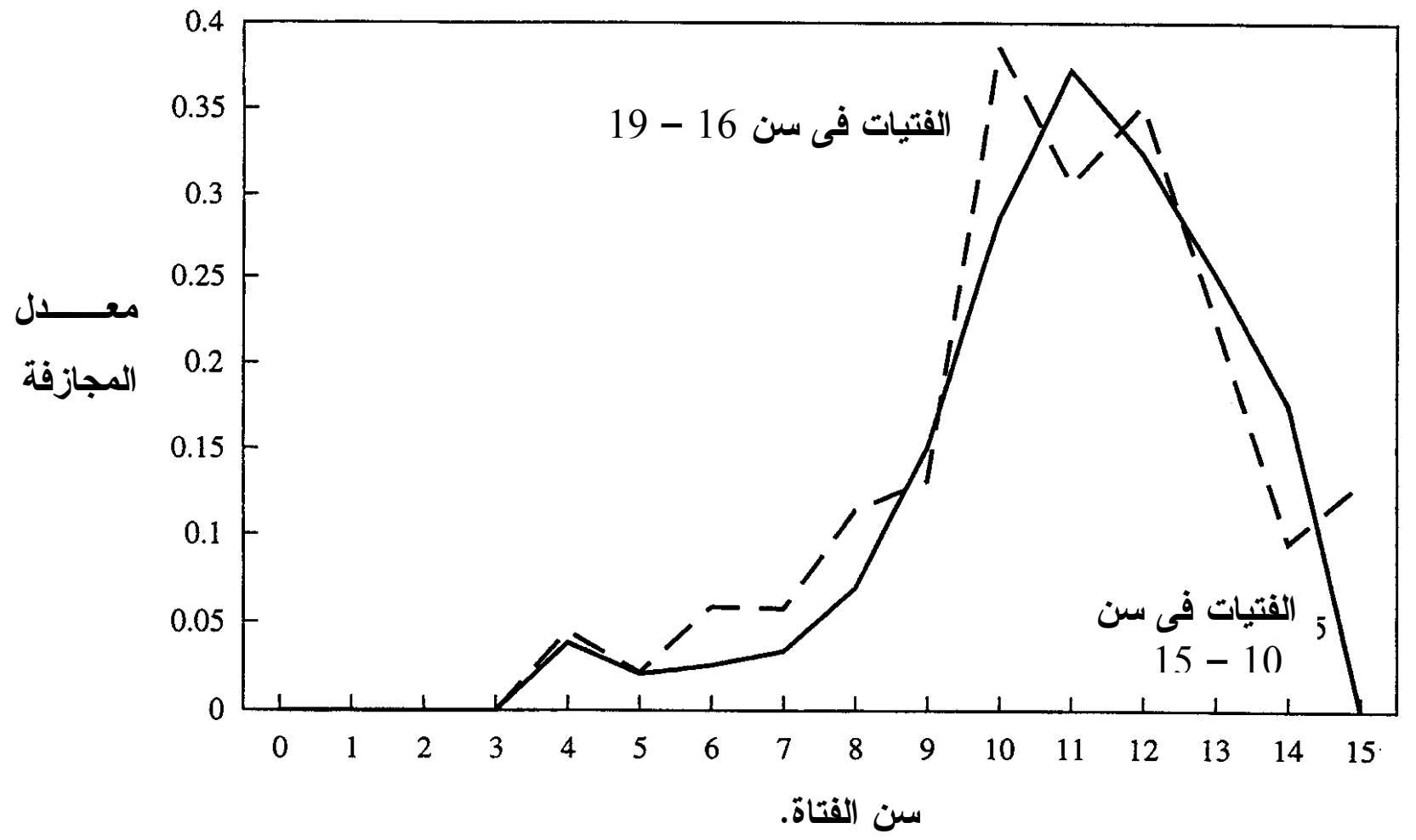

ولكن لا يمكنتا بالتأكيا استبعاد الفكرة تماماً بأن العمر عند الختان يتزايد حالياً في مصر وبالتالي فإن الفتيات الأصغر عمراً في العينة سن 10 - 12 سنة سيتم ختانهن في مرحلة لاحقة. فربما أن الآباء نتيجة لوعيهم بالدعاية السلبية المحيطة بهذه الممارسة، قد اختاروا تأخير ختان بناتهم، ومع مرور فئه

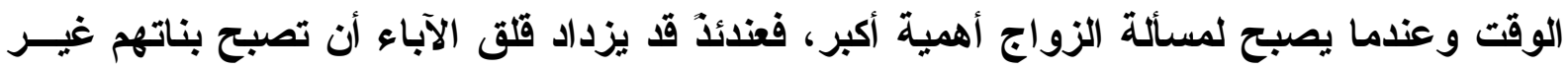

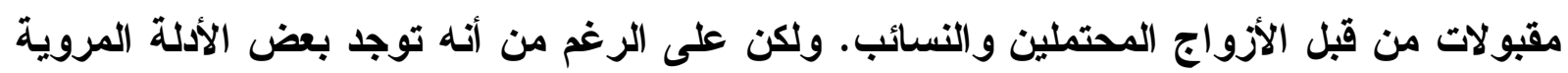




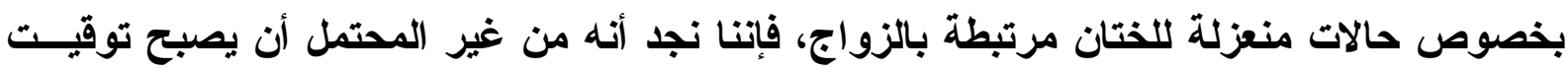

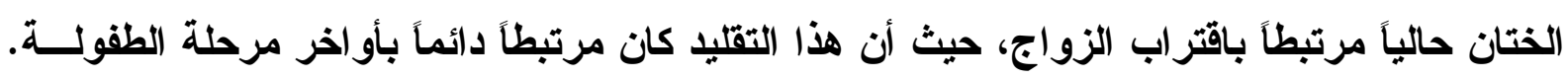

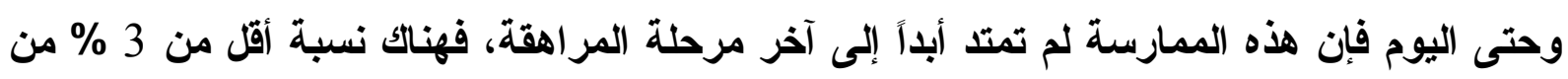

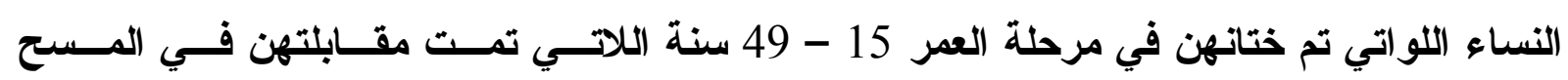
الايموجرافى DHS ومن البنات المختنات لهؤلاء النساء، قد تعرضن لهذه العملية بعد سن 12 سنة. و إضافة إلى ذلك فمن بين 846 فتاة في عينة مسح مرحلة المراهقة ASCE اللو اتي تـــ ختــانهن

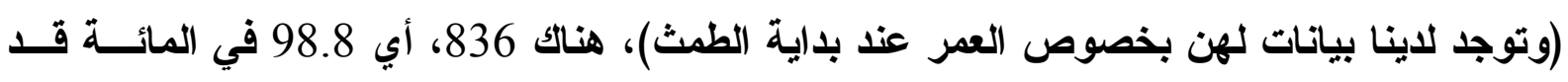
أجريت لهن العملية عند نفس السن (6.3 في المائة) أو قبل نزول الطمث (92.6 في المائة).

من التي بتث ختانها؟

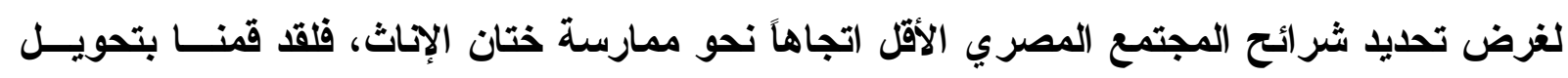

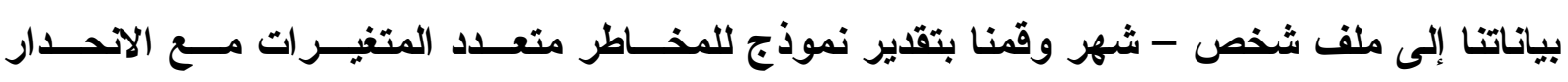

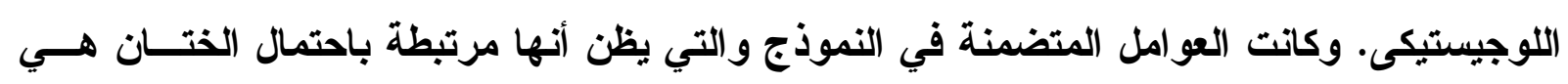

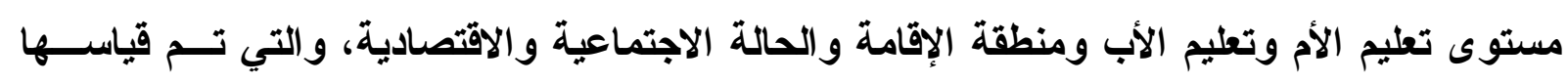
بمؤشر الاستهلاك ويشمل 1- أحوال وحدة الإسكان و2- ملكية السلع المعمرة و 3- ملكية الأصول

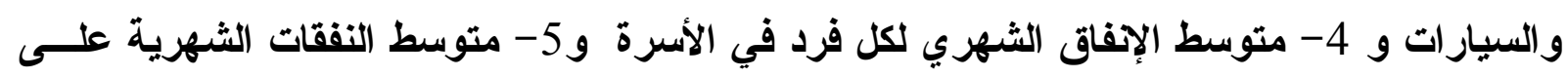

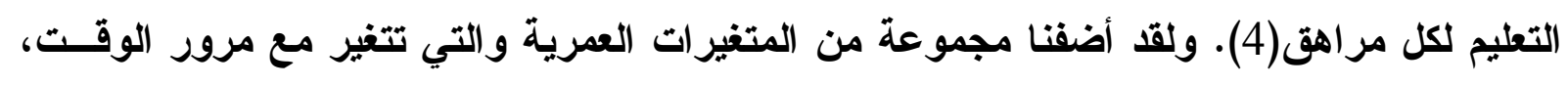

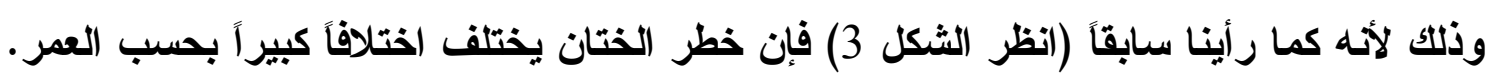
ولغرض بحث ما إذا كان احتمال الختان يختلف بالارتباط مع الأحداث الزمنية في مصر، قمنا بتضمين

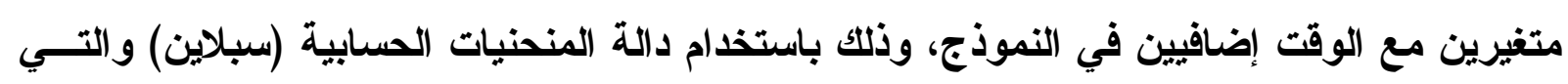

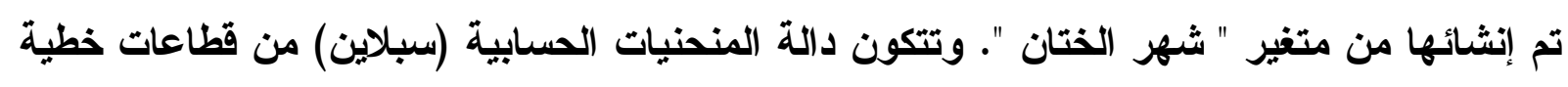
يتم توصيلها عند نقطة محددة أو " عقدة "، في هذه الحالة هى شهر يناير 1995. و و تقوم المعاملات

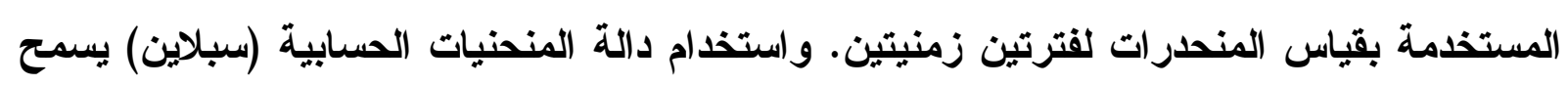

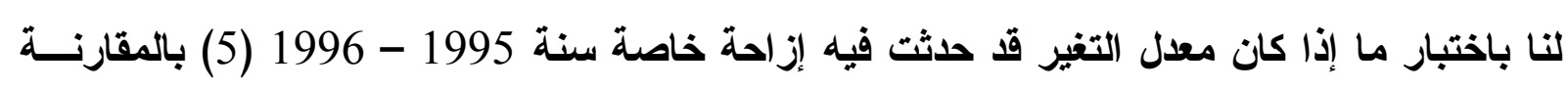

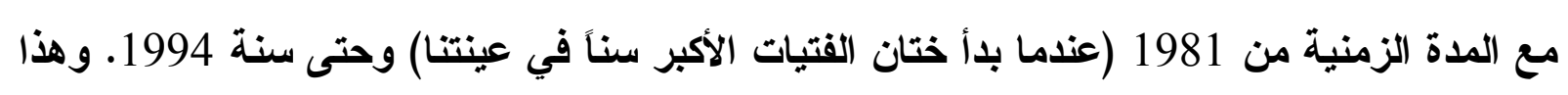


يعني أننا نختبر صراحة ما إذا كان خطر الختان قد تغير بعد المؤتمر الاولى للسكان والتنمية ICPD في أواخر سنة 1994.

ويقدم الجدول 2 نسب الاحتمالات الترجيحية وكذلك الاحتمالات المرتبطة بكل متغير . وكما يمكتنا أن

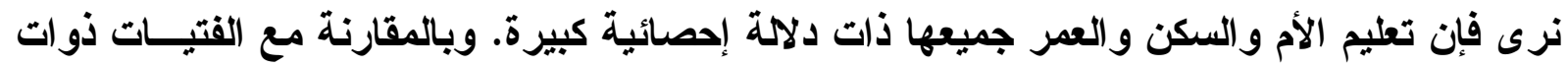

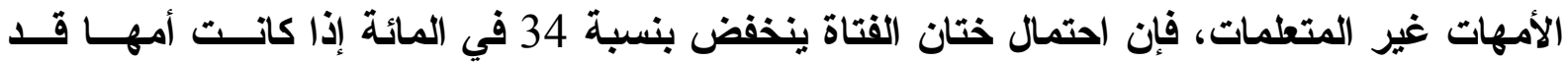
حصلت على تعليم فنى وبنسبة 64 في المائة إذا كانت الأم قد حصلت على تعليم ثانوى. وهناك تأثير حدي واضح بالنسبة للتعليم، فبنات الأمهات اللاتي ذهبن إلى مدرسة ابتدائية (السنوات الدراسـية 1 الدئ - 5) أو إلى مدرسة إعدادية (السنوات الدراسية 6 - 8) لا يقل احتمال ختانهن معنويا عـن بنــات

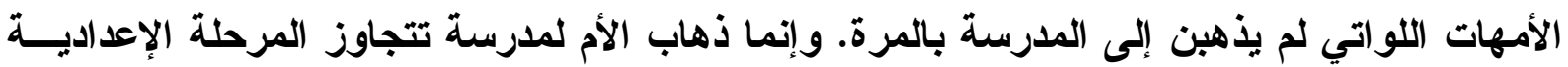

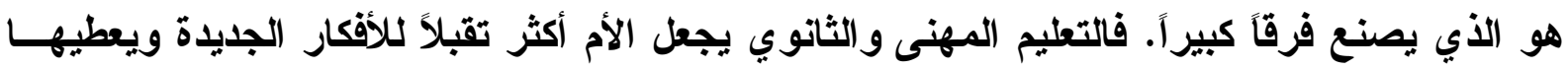

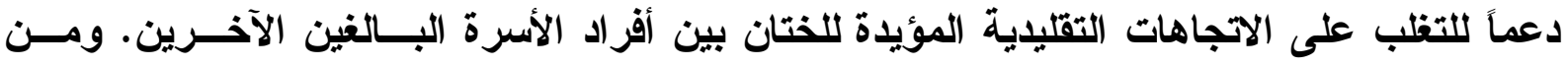
الغريب أن تعليم الأب لا يقلل بلرجة معنوية من احتمالات الختان. كمـــأن أن الأوضـــاع الاجتماعيــة و الاقتصادية التي تم قياسها على أساس مؤشرات الاستهلاك ليس لها تأثير أيضاً. و الفتيات اللاتي يعشن في محافظات حضرية وفي المناطق الحضرية للوجه البحرى لمصر، هن أقــل احتمالا للتعرض للذتان بنسب 31 في المائة و 28 في المائة على التوالى من الفتيات اللواتي يعشن في المناطق الريفية في صعيد مصر ـ وهكذا فإن المتغيرات المتعلقة بالسكن تظل ذات دلالة معنويــة حتى بعد عزل تأثير المتغيرات الاجتماعية والاقتصادية الأخرى وهذا الأمر جدير بالملاحظة. وهــــا يثير إلى أن هناك تأثير انتثاري فيما يتعلق بالقرار الخاص بختان البنت. فالبالغين الذين يعيسشون

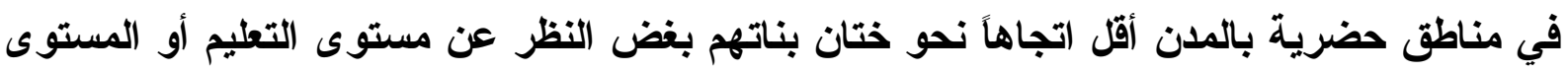

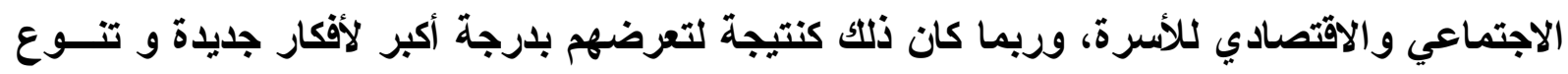
العادات والسلوكيات. أما المتغير الأخير ذي الدالاة المعنوية في التوزيعات الديموجرافية فهو السن.

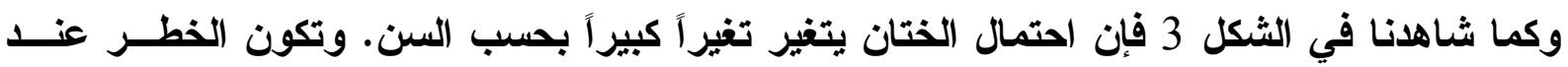
أعلي ما يمكن في سن 10 - 12 و أقل ما يمكن في سن أقل من 8 وأكثر من 14. 
جدول 2 نموذج معدل خطر احتمال الختان للفتبات المصريات فحى سن 10 - 19 (2) (N=1.236).

\begin{tabular}{|c|c|c|}
\hline P القيمة P P & الترجسبية الاحتمــــالات & 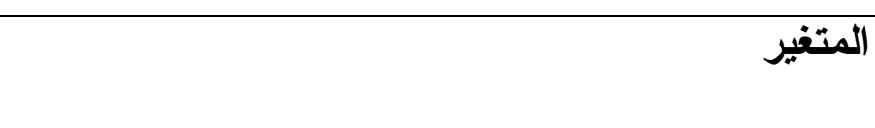 \\
\hline & & تعليم الأم (محذوف = لا يوجد) \\
\hline 1.000 & 1.00 & تعليم ابتدائي غير كامل \\
\hline 0.239 & 0.88 & تعليم ابتائي كامل / أي تعليم إعدادي \\
\hline 0.022 & $* 0.66$ & تعليم حرفى،فوق المتوسط \\
\hline 0.000 & *** 0.36 & أي تعليم ثانوي فأعلى \\
\hline \multirow[t]{2}{*}{0.494} & 1.10 & غير موجود \\
\hline & & تعليم الأب (محذوف = لا يوجد) \\
\hline 0.144 & 1.18 & تعليم ابتدائي غير كامل \\
\hline 0.800 & 1.03 & تعليم ابتدائي كامل / أي تعليم إعدادي \\
\hline 0.799 & 1.04 & تعليم حرفى، فوق المتوسط \\
\hline 0.200 & 0.78 & أي تعليم ثانوي فأعلى \\
\hline \multirow[t]{2}{*}{0.074} & 1.19 & غير موجود \\
\hline & & الحالة الاجتماعية و الاقتصادية (محذوفة = منخفضة) \\
\hline 0.615 & 1.04 & متوسطة \\
\hline \multirow[t]{2}{*}{0.201} & 1.12 & 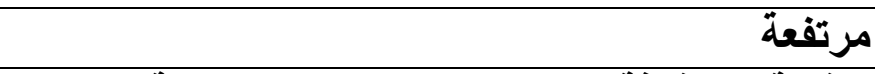 \\
\hline & & الإقامة (محذوفة = صعيد مصر، مناطق ريفية) \\
\hline 0.004 & $\because * 0.69$ & المحافظات الحضرية \\
\hline 0.016 & $* 0.72$ & وجه بحرى، مناطق حضرية \\
\hline 0.163 & 0.88 & وجه بحرى، مناطق ريفية \\
\hline 0.113 & 0.80 & صعيد مصر، مناطق حضرية \\
\hline 0.002 & $* * 1.00$ & شهر الختان في حالة الختان في السنوات 1981 - 94 \\
\hline \multirow[t]{2}{*}{0.124} & 0.99 & شهر الختان في حالة الختان في السنوات 1995 - 96 \\
\hline & & السن (محذوف = > 8 سنوات) \\
\hline 0.000 & **** 5.52 & $9-8$ \\
\hline 0.000 & $* * * 17.96$ & $12-10$ \\
\hline 0.000 & **** 11.34 & $14-13$ \\
\hline 0.541 & 1.39 & $19-15$ \\
\hline
\end{tabular}

2 - يمتل التحليل فقط حتى نهاية سنة 1996 حيث أن البيانات لا تغطي سنة كاملة للتعرض للخطـر سنة 1997. ولقد تم استبعاد 59 حالة غير معروفة العمر عند الختان.

$$
0.001>\mathrm{P}^{* * *} \quad 0.01>\mathrm{P}^{* *} \quad 0.05>\mathrm{P}^{*}
$$


وبينما لا يوجد أي متغير آخر في النموذج ذو تأثير معنوي، من المفيد أن يتم النظر باختصار فــي

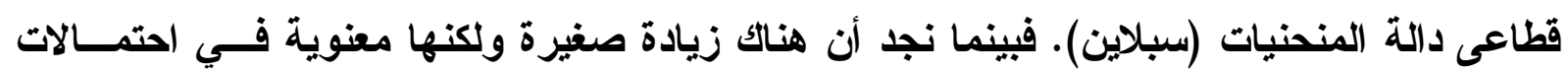

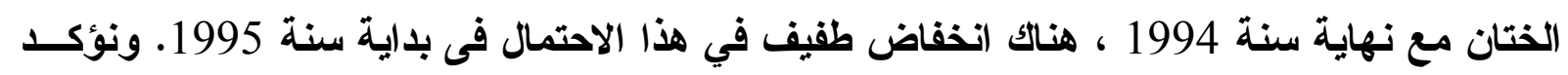

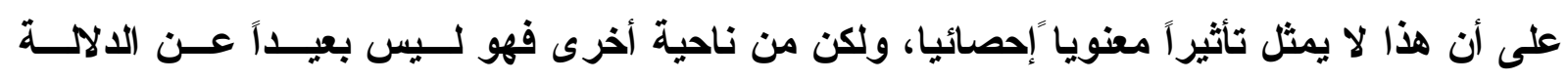

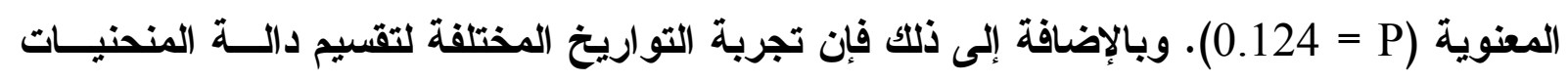
الحسابية (سبلاين) (بتحريك الحاجز إلى نهاية سنة 1993 أو نهاية سنة 1995 على سبيل المثـال) فإن هذا يبين أن يناير 1995 يعطى أقوى النتائج. وهكذا وعلي الرغم من أن المستح القومي لمرحلة

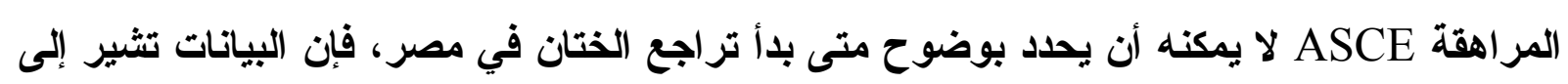

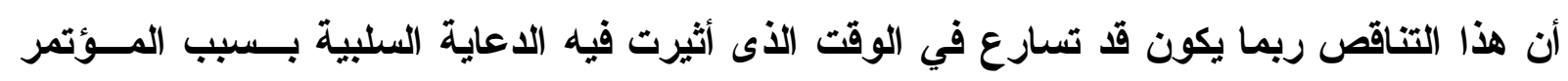

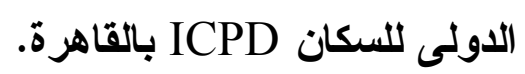

\section{هل تفسر زيادة مستوى التعليم هذا التفيرج}

تقدم بيانات مسح المراهقة و التغير الآجتماعى ASCE التقديرات الأولي على المـستوى القــومي

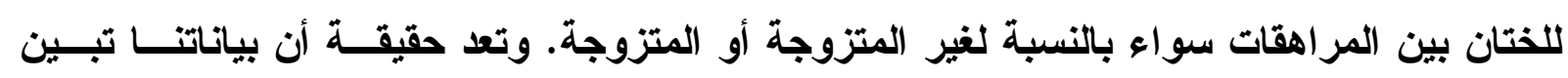

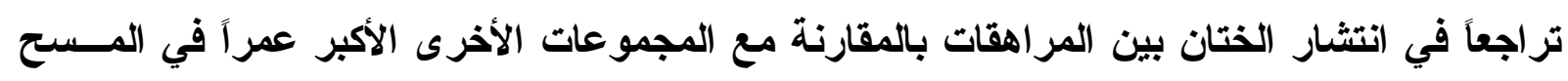
الديموجرافى DHS جديرة بالملاحظة. ولقد أثرنا إلى أن التناقص الظاهر في انتثار الختان يمكـن

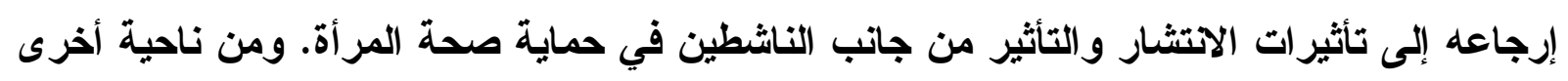

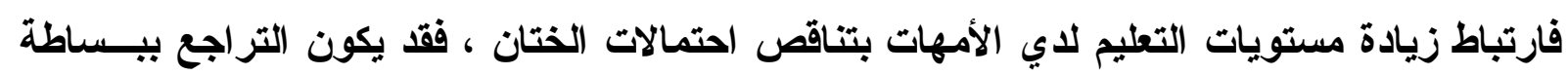

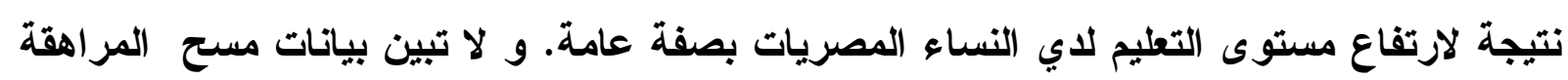

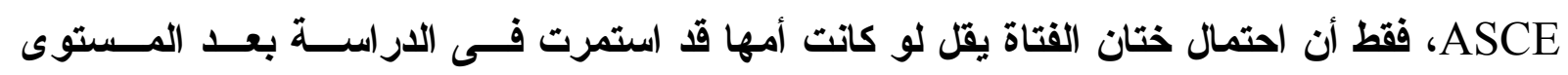

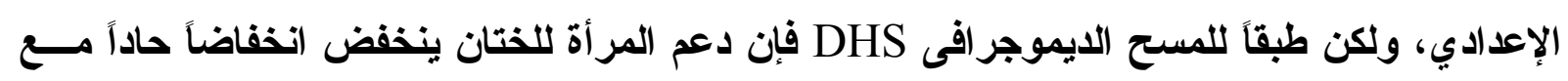
زيادة المستوى التعليمي. وهناك فقط نسبة 56.5 في المائة من النساء المتزوجات من ذوات التطليم

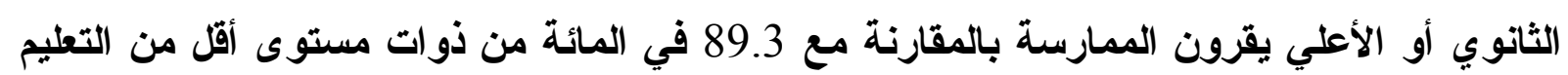

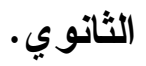

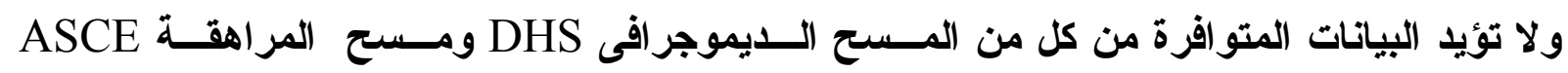

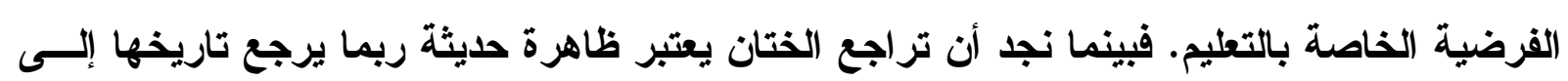


التسعينات أو ربما الثمانينات، فقد بدأ المستوى التعليمي للمرأة في الارتفاع في الخمسينات عنــما

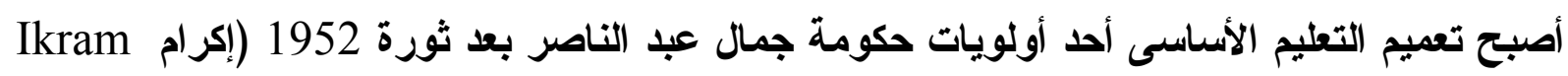

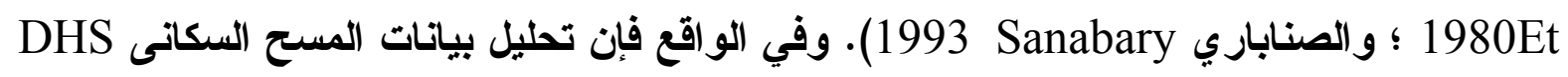

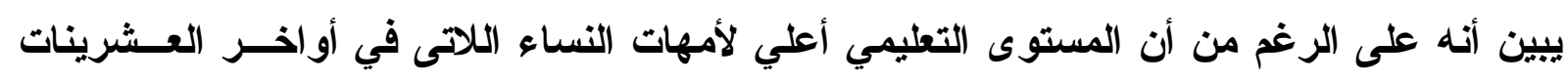

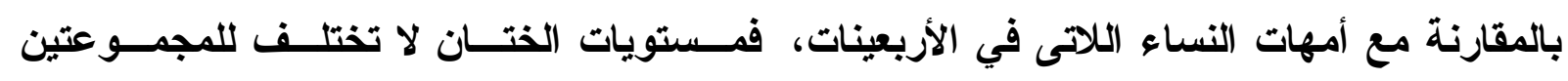
العمريتين. على سبيل المثال فهناك نسبة 97 في المائة من النساء فى سن 25 - 29 تم ختــانهن، فنفس هذه النسبة المئوية تقريبا سجلت للنساء فى سن 45 - 49 (6). فأمهات النساء في سن 25 - 29 يكن في المتوسط في الخمسينات (7) و أمهات النساء فى سن 45 - 49 يكن فــى المتوســ لهـ

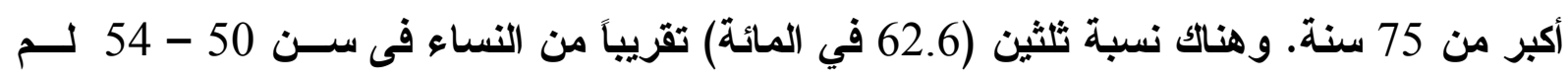

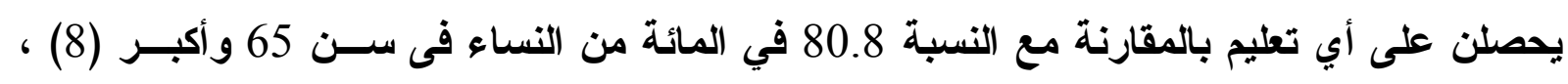

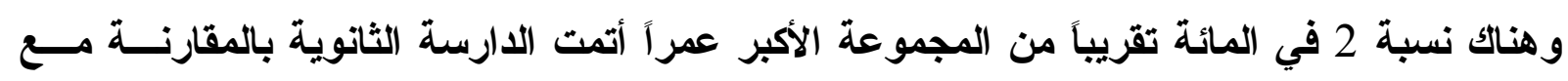
حوالي 10 في المائة من النساء فى سن 50 - 54. (9) وهذا يفيد بأن ارتفاع مستويات التعليم من

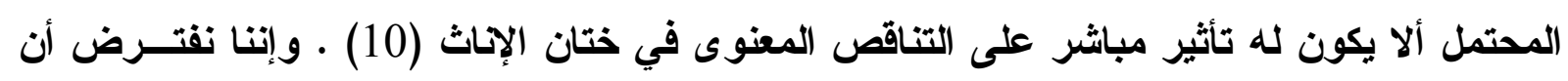
التعليم يعتبر أحد المتغيرات الوسيطة الهامة والتي تعمل من خلالها عمليات أخـــى مثــل انتـشـار

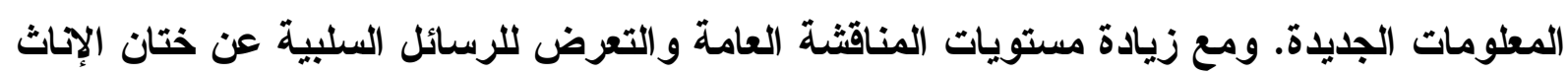

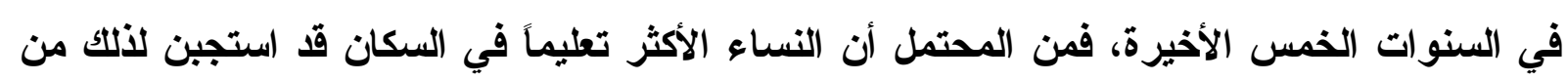
خلال الامتناع عن ختان بناتهن.

وبالإضافة إلى ذلك فإن التناقص حيثا في معدلات الختان والملحوظ في بيانــات مسـسح المراهقــة

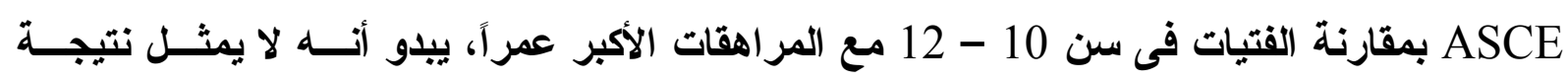

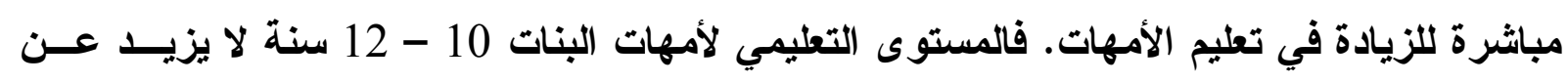
المستوى التعليمي لأمهات البنات فى سن 13 - 15 أو 16 - 19. وفي الحقيقة فإن نسبة العهات 36.1 في

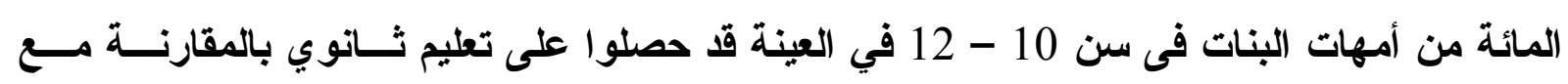

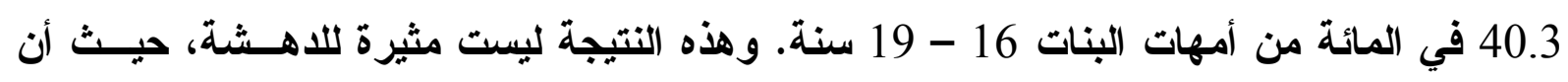
متوسط الفارق بين أمهات البنات في المجموعتين العمريتين 7.5 سنة فقط وهى فترة قصيرة جـــاً لاكتثاف أي تغير كبير في المستوى التعليمي. (11) 
الأدلة الأخرى على التغيير : المحبط الاجتماعي واضفاء الطابع الطبي على الختان يمكنتا أن نتوقع أن الاخففاض في اتجاه الأسر نحو ختان البنات يمكن أن يكـون مـصحوياً أيـضاً

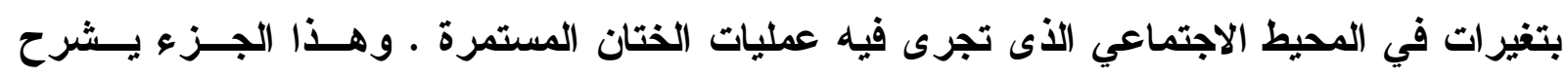

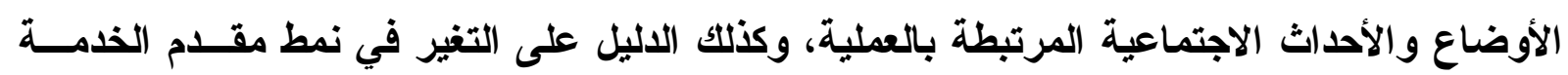
الأي يقوم بالختان.

فالختان مناسبة اجتماعية لديها دلاة خاصة في حياة الفتاة (أسعد 1980Assaad : 5). فهو يمثـل

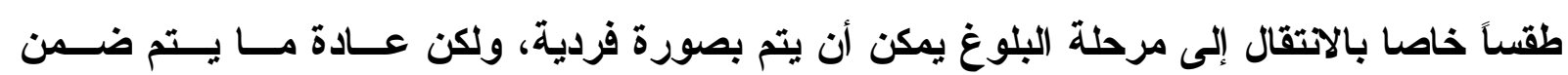
مجموعة من الفتيات في نفس الوقت. وقث أفادت أكثر قليلا من النصف (52.5 في المائة) من البنات

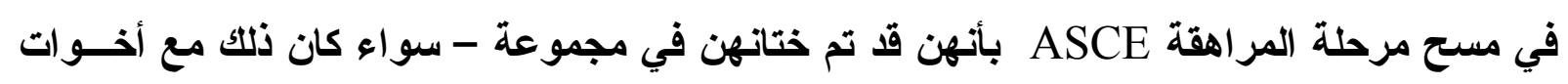

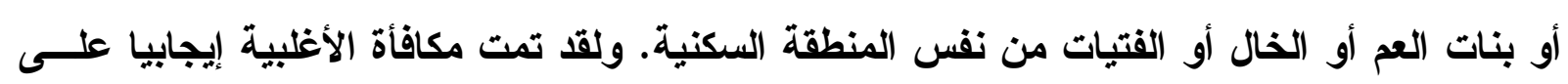

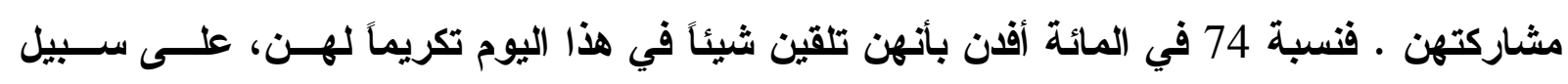

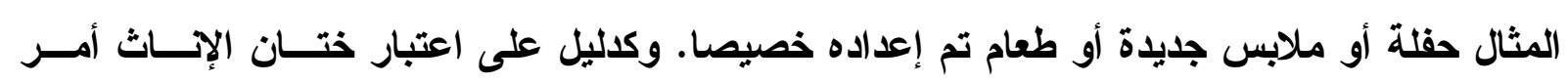

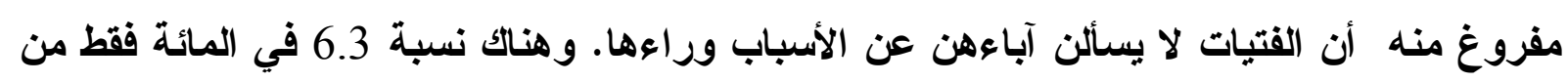

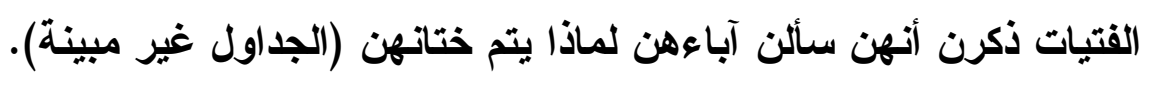

وجه المسح الديموجر فى DHS عام 1995 في مصر الاتتباه لزيادة نسبة عمليات الختان التي تــتم

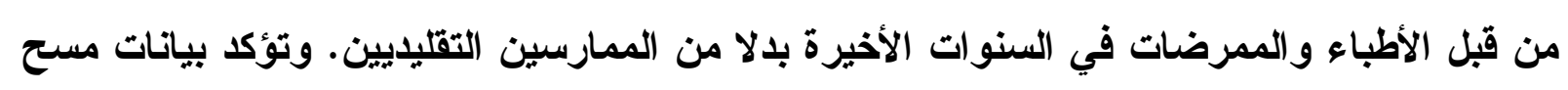
مرحلة المراهقة ASCE الاتجاه نحو اضفاء الطابع الطبي على الختان. وفي المسح الـديموجر افى ولى

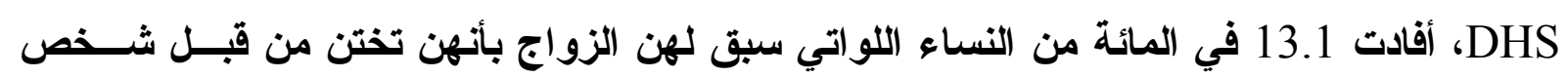

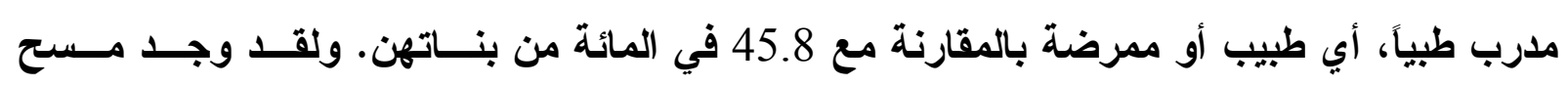

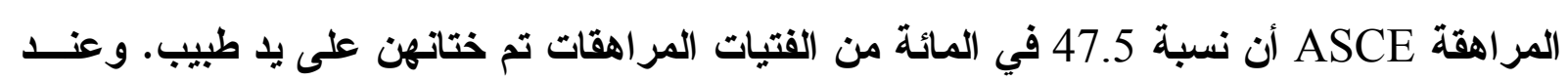
حساب الأطباء بالإضافة إلى الممرضات للمقارنة مع المسح الديموجرافى DHS فإن الإجمالي يصل

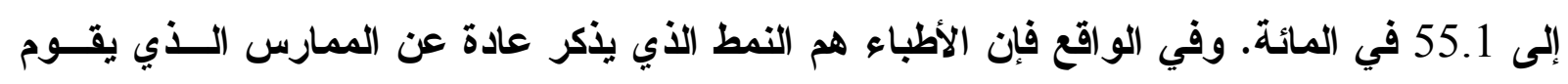

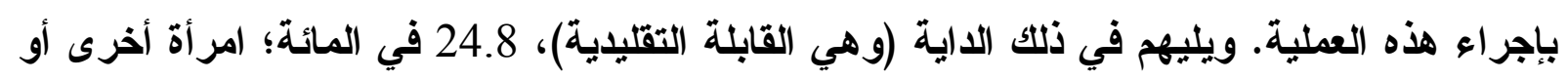


رجل في المجتمع متخصص في إجراء هذه العملية , 10.8 في المائة؛ الممرضات،7.6 في المائسـة؛

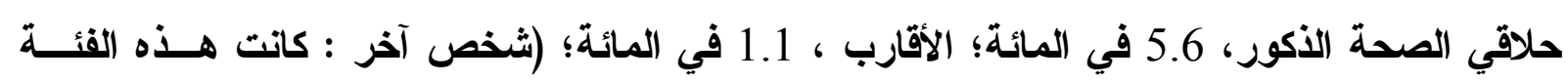
تعادل 2.6 في المائة ؛ الجدول غير مبين). علي الرغم من زيادة مشاركة الأطباء، فإن نسبة ثلاثة أرباع من عمليات الختان (75.2 في المائسـة)

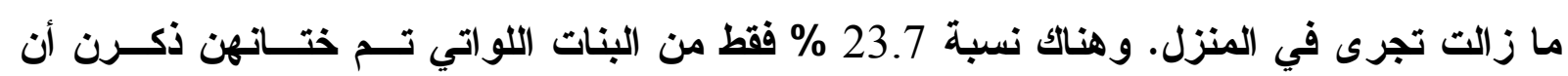

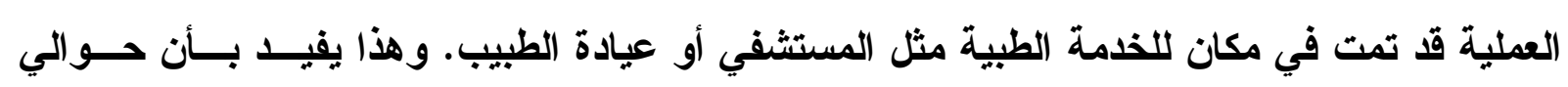

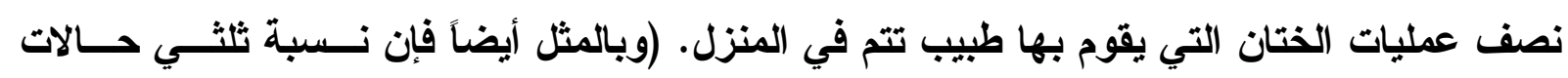
الولادة مازالت تتم في المنازل في مصر على الرغم من التظلي عن الولادات عن طريق الداية لصالح

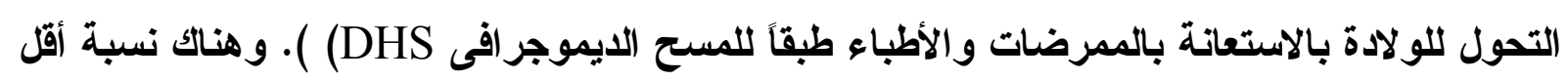

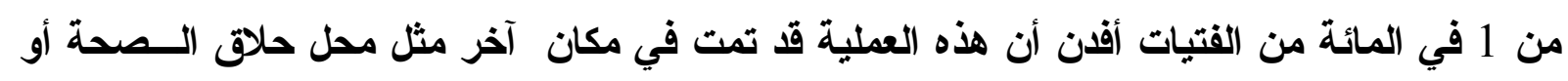
في المولا (الاحتفال الديني). 
جدول 3 : نموذج الانحار اللوجيستيكى) للخصائص المرتبطة بالختان بالاستعانة بالطبيب، بالنسبة

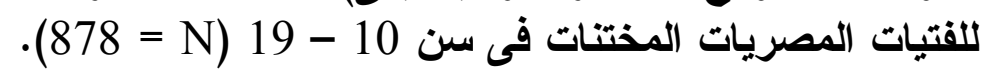

\begin{tabular}{|c|c|c|}
\hline P القيمة P & الترجيحبة الاحتـــــــالات & 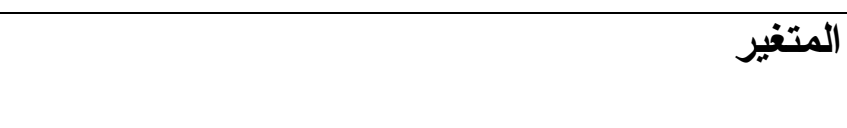 \\
\hline & & تعليم الأم (محذوف = لا يوجل) \\
\hline 0.652 & 1.05 & تعليم ابتدائي غير كامل \\
\hline 0.017 & *1.34 & تعليم ابتدائي كامل / أي تعليم إعدادي \\
\hline 0.359 & 1.19 & تعليم حرفى، فوق المتوسط \\
\hline 0.189 & 1.53 & أي تعليم ثنانوي فأعلى \\
\hline 0.318 & 0.87 & غير موجود \\
\hline & & تعليم الأب (محذوف = لا يوجد) \\
\hline 0.494 & 1.09 & تعليم ابتدائي غير كامل \\
\hline 0.454 & 1.09 & تعليم ابتدائي كامل / أي تعليم إعدادي \\
\hline 0.007 & $* * 1.58$ & تعليم حرفى، فوق المتوسط \\
\hline 0.974 & 1.01 & أي تعليم ثانوي فأعلى \\
\hline 0.114 & 1.19 & غير موجود \\
\hline & & الحالة الاجتماعية و الاقتصادية (محذوفة = منخفضة) \\
\hline 0.369 & 1.09 & متوسطة \\
\hline 0.048 & *1.21 & 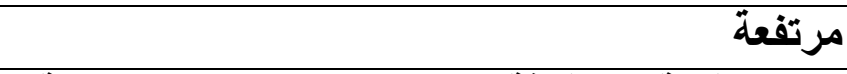 \\
\hline & & محل الإقامة (محذوفة = صعيد مصر، مناطق ريفية) \\
\hline 0.000 & $* * * 1.67$ & المحافظات الحضرية \\
\hline 0.040 & $* 1.39$ & وجه بحرى، مناطق حضرية \\
\hline 0.655 & 1.04 & وجه بحرى، مناطق ريفية \\
\hline 0.185 & 1.20 & صعيد مصر ، مناطق حضرية \\
\hline 0.328 & 1.04 & السن عند الختان \\
\hline 0.69 & 1.06 & سنة الختان \\
\hline 0.238 & 0.84 & (الختان في 1996-1981-1997-1995) \\
\hline
\end{tabular}

$$
0.001>\mathrm{P}^{* * *} \quad 0.01>\mathrm{P}^{* *} \quad 0.05>\mathrm{P} *
$$

ويبين الجدول 3 الاحدار اللوجيستيكي للخصائص المرتبطة بالفتيات اللواتي تم ختانهن عن طريـق

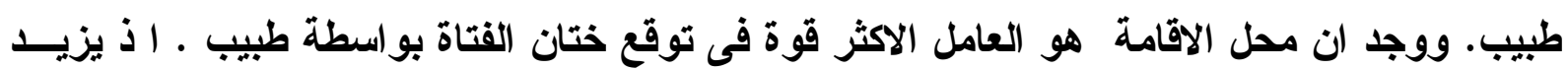




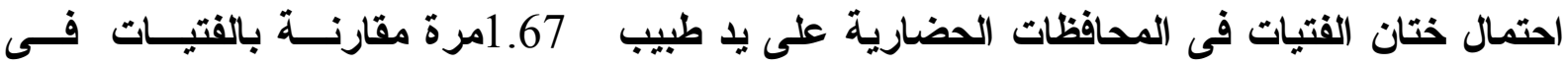
المناطق الريفية بوجة قبلى كما يرتفع احتمال الختان على يد طبيب 1.39 مرة بين الفتيات المقيمات

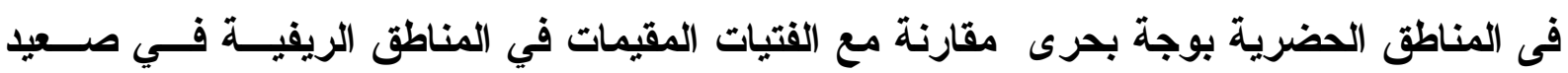

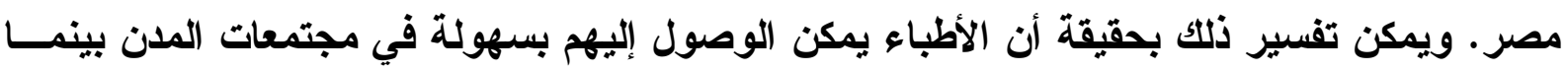

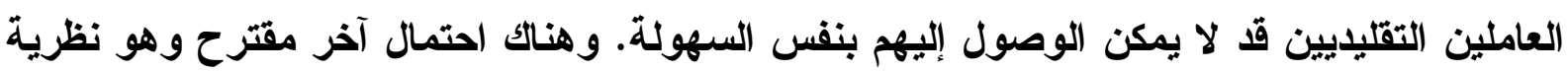
الانتثار الاجتماعي حيث أن الأسر في المدن تتعرض بلدرجة أكبر لرسائل التثقيف الصحي والتــي لوني

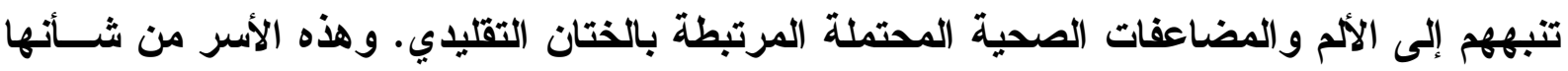
أن تلجأ بنسبة أكبر للأطباء لغرض التخفيف من هذه النتائج السلبية.

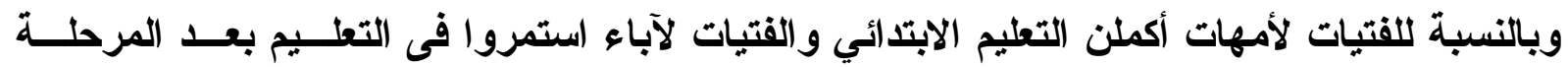

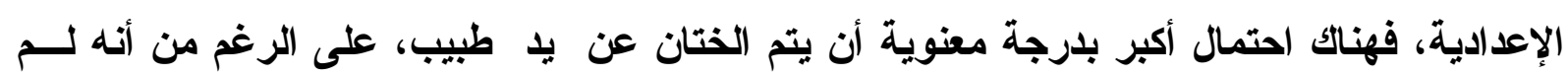

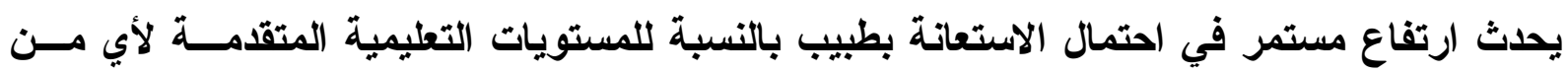

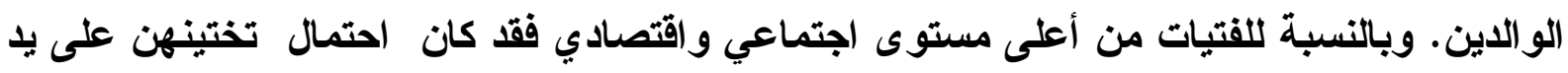
طبيب اكبر 1.21 مرة. وهذه النتائج عند تجميعها معاً تفيد بأن الوضع الاقتصادي يمكن أن يكون أحد العوامل المؤثرة في اختيار طبيب بدلاً من الممارسين التقليديين.

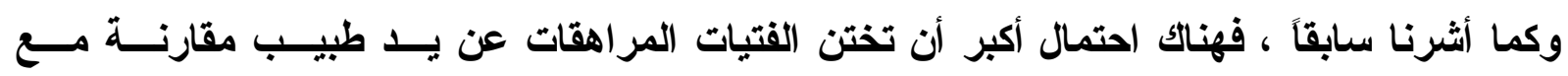

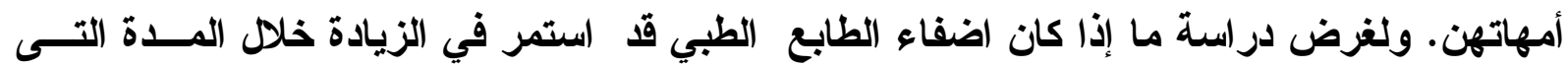
كاتت فيها عينة مسح المراهقة معرضة لخطر الختان ASCE ، فقد أضفنا متغير آخرا وهو " سنة

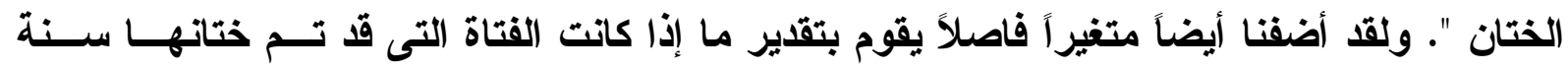
1996 أو 1997 كان احتمال ذهابها لطبيب أقل وذلك بعد الحظر الذي تمت اســتعادته ســـنة 1995 لمنع عمليات الختان عن طريق طبيب في المستثفيات العامة. وتتجه معاملات سنة الختان والمتغير

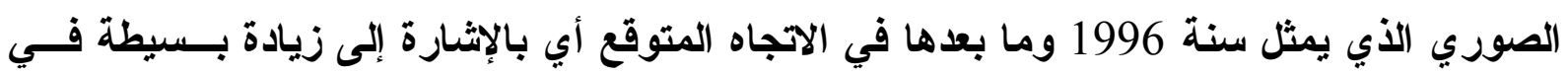
اضفاء الطابع الطبي حتى سنة 1995 ويلي ذلك ما قد يكون بدايات التزاجع. ولكن أي من المؤشرين

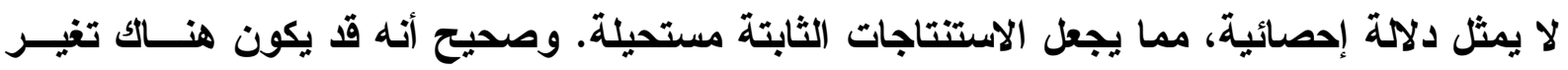

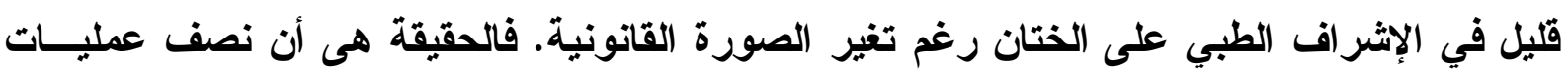
ختان الإناث في مصر تقريباً مازالت تتم بصورة غير قانونية عن طريق الأطباء. 
وبجمع هذه النتائج معاً، فإن النتائج الخاصة بتراجع الانتثار وارتفاع معدل اضفاء الطابع الطبي تفيد

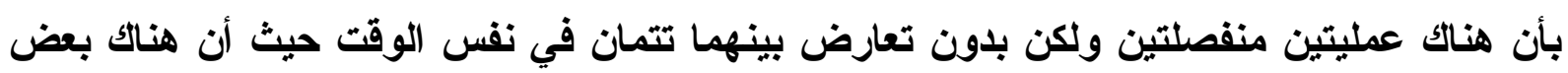

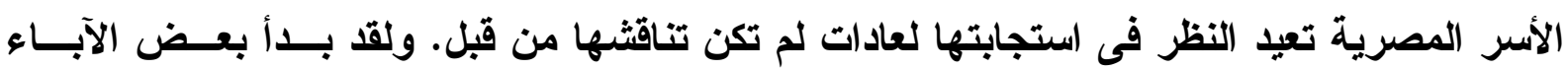
يقررون أن الحجج ضد الختان تفوق المزايا المنتظرة وهكذا فإنهم يختارون عـدام ختـــان بنــاتهن.

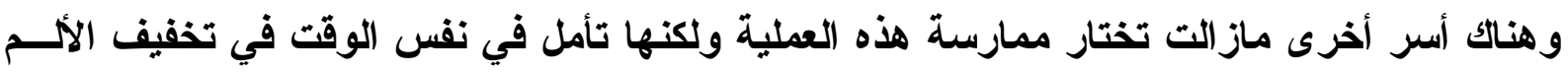

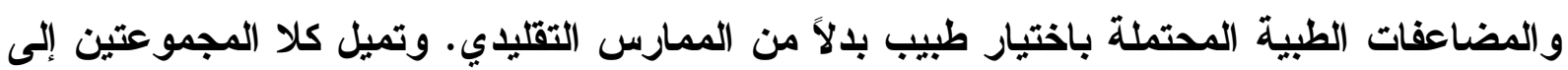
التواجد في المناطق الحضرية، مما يؤيد نموذج التغيير على أساس الاتثثار الاجتمــاعي. فالإقامــة

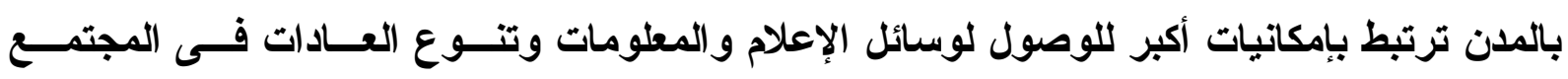
وسهولة الوصول للأطباء.

\section{اتجاهات الفتبات اللاتي نت ختانهين من الفئة العمرية 10 - 19 سنة}

تم سؤال الفتيات اللواتي تعرضن للختان ما إذا كن يرون أن الختان ضروري ومهم بالنسبة للفتــاة. ولقد قالت نسبة 13.6 في المائة من الفتيات اللواتي تم ختانهن أنهن يعتقدن بأن هذه العملية غيـر ضرورية ، فيما اجابت نسبة 28.4 في المائة أجابت بأنهن لا يعرفن، وصرحت نسبة 58 في المائة قلن أن هذه العملية ضرورية وهامة. و إذا جمعنا بين الآراء التي تعبر عن الرأي المحايد أو التأرجح وتلك التي تري أن هذه العملية غير ضرورية فإن هذا يعطى نسبة كبيرة 42 فى المائة من الفتيـات اللو اتي تم ختانهن غير مقتنعات بضرورة هذه العملية.

ولغرض تقدير خصائص الخلفية التي يرجح أن تكون مرتبطة بنقص التأييد لعملية الختان، فلقد تــم

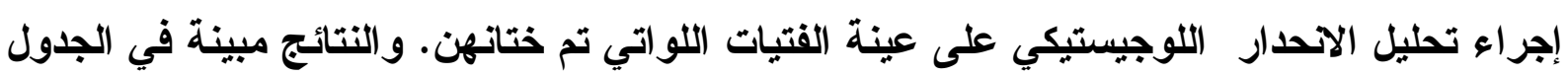
4 حيث تثمل المتفيرات المستقلة العمر الحالي للمراهقة و المستوى الاراسي الحالي بالإضافة إلـى

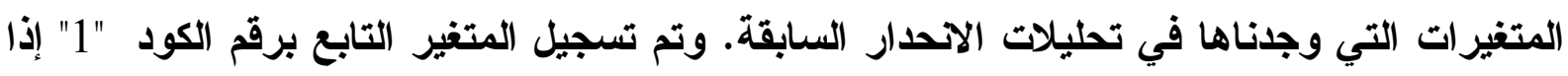

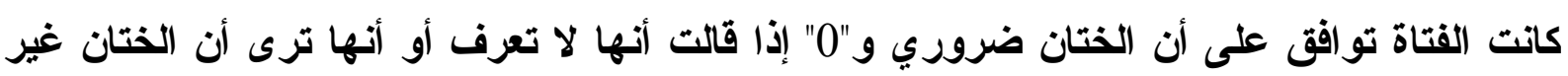

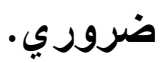

و هناك من العوامل مثل السن والاراسة والإقامة بالمحافظات العضرية ما هو مرتبط ارتباطاً ســلبياً

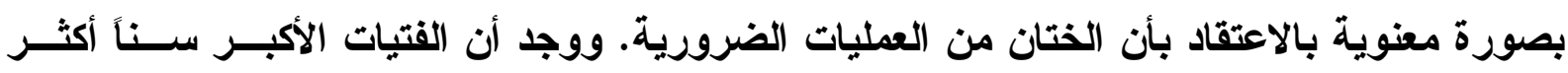
احتمالا أن يعارضن ضرورة الختان، وهي نتيجة تثير الاهتمام إذا وضعنا في الاعتبار الاحتمال الأكبر 
في أن يكن قد تعرضن للختان كما ذكرنا سابقاً. ومن الناحية التقليدية في مصر، فلقــــــــان هنــاك

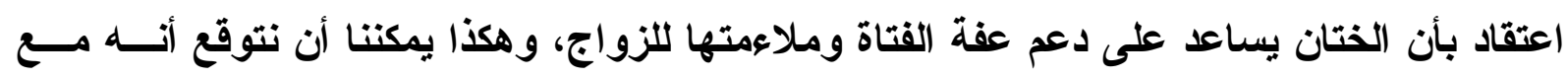

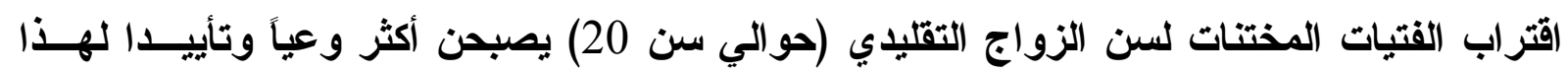

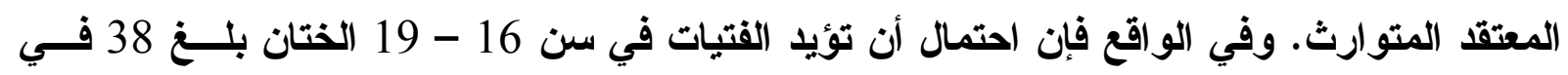
المائة مثل الفتيات في المجموعة العمرية الأصغر 10 - 12 سنة. ولقد افترضنا أن الفتيات الأصغر

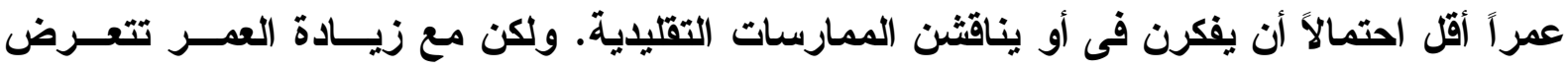

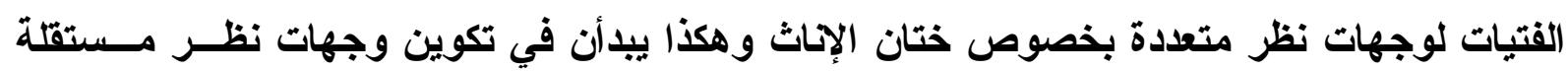
بخصوص ذلك. وترتبط الاتجاهات بخصوص الختان ارتباطاً وثيقاً بلخول المدرسة. فاحتمال ان تؤيد الفتيــات فــي المراحل الاراسية حالياً والفتيات اللاتي ذهبن للمدرسة في الماضي الختان أقل بالمقارنة مع الفتيات اللواتي لم يذهبن للمدرسة قط. وهذا الارتباط مستمر بغض النظر عن المستوى التعليمي للأم أو الأب أو الوضع الاجتماعي والاقتصادي للأسرة. وفي السنوات الأخيرة بدأت المناهج الدراسية في تقــــيم

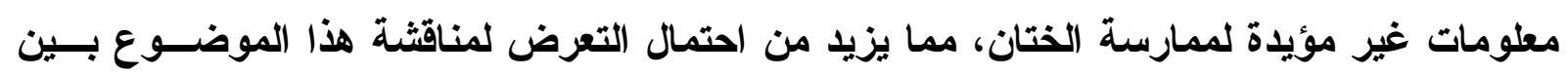
الفتيات اللاتى بالمدارس حالياً. 
جدول 4 : نموذج الاحدار اللوجيستيكى للخصائص المرتبطة بمفهوم أن الختان ضروري، بالنسبية للفتيات المصريات المختنات في سن 10 - 19 ( N ) 903).

\begin{tabular}{|c|c|c|}
\hline 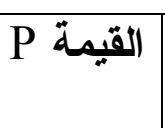 & نتـــــــبة الاحتــــــالات & 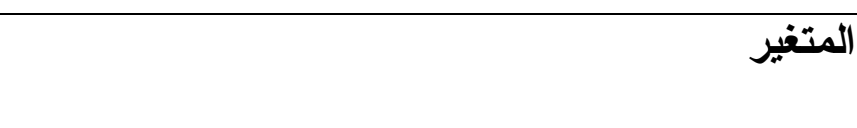 \\
\hline & & تعليم الأم (محذوف = لا يوجل) \\
\hline 0.331 & 1.18 & تعليم ابتدائي غير كامل \\
\hline 0.294 & 1.20 & تعليم ابتدائي كامل / أي تعليم إعدادي \\
\hline 0.063 & 0.67 & تعليم حرفى، فوق المتوسط \\
\hline 0.846 & 0.94 & أي تعليم ثانوي فأعلى \\
\hline \multirow[t]{2}{*}{0.887} & 1.03 & غير موجود \\
\hline & & تعليم الأب (محذوف = لا يوجد) \\
\hline 0.967 & 1.01 & تعليم ابتدائي غير كامل \\
\hline 0.840 & 0.97 & تعليم ابتدائي كامل / أي تعليم إعدادي \\
\hline 0.439 & 0.85 & تعليم حرفى، فوق المتوسط \\
\hline 0.534 & 0.86 & أي تعليم ثانوي فأعلى \\
\hline \multirow[t]{2}{*}{0.952} & 1.01 & غير موجود \\
\hline & & الحالة الاجتماعية و الاقتصادية (محذوفة = منخفضة) \\
\hline 0.889 & 0.98 & متوسطة \\
\hline \multirow[t]{2}{*}{0.845} & 0.97 & 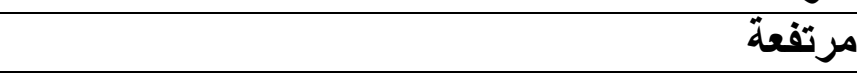 \\
\hline & & الإقامة (مدذوفة = صعيد مصر، مناطق ريفية) \\
\hline 0.006 & *** 0.62 & المحافظات الحضرية \\
\hline 0.404 & 0.83 & وجه بحرى، مناطق حضرية \\
\hline 0.575 & 1.09 & وجه بحرى، مناطق ريفية \\
\hline \multirow[t]{2}{*}{0.344} & 0.84 & صعيد مصر ، مناطق حضرية \\
\hline & & المجموعة العمرية (محذوفة = 10 - 12) \\
\hline 0.003 & ** 0.60 & $15-13$ \\
\hline \multirow[t]{2}{*}{0.000} & $* * * 0.38$ & $19-16$ \\
\hline & & حضور المدرسة (محذوف = لم تذهب أبداً للمدرسة) \\
\hline 0.041 & $* 0.34$ & ذهبت للمدرسة في الماضي \\
\hline 0.003 & *** 0.21 & في المراحل الدراسية حالياً \\
\hline & $0.001>\mathrm{P}$ & $0.01>\mathrm{P}^{* *}$ \\
\hline
\end{tabular}

ويبدو أن التغيرات في التوجهات لاي الفتيات المختنات قد تم تثجيعها من خلا الاتثشار الاجتماعي

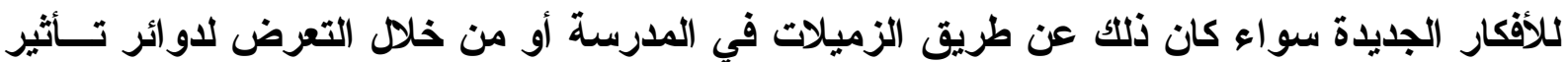


أوسع. والمناطق الحضرية تقدم نسقاً مماثلاً. فمن بين الفتيات في مسح المراهقة ASCE المقيمات

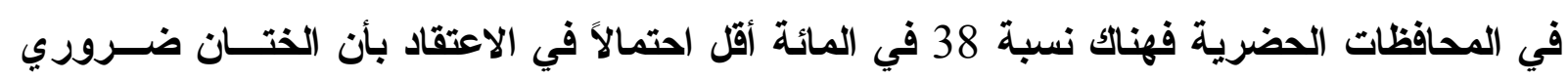

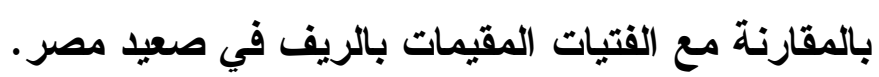

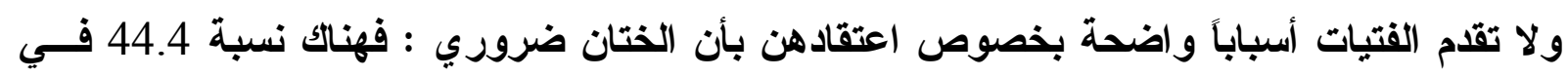

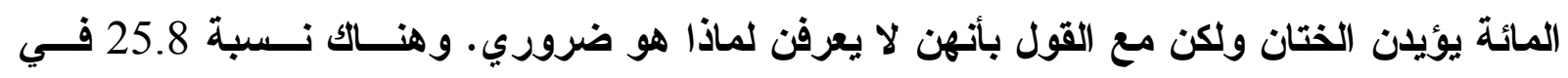

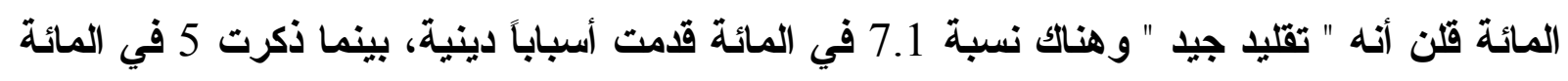

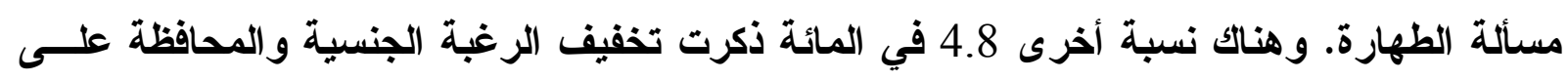

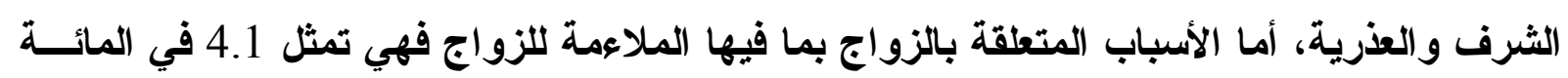

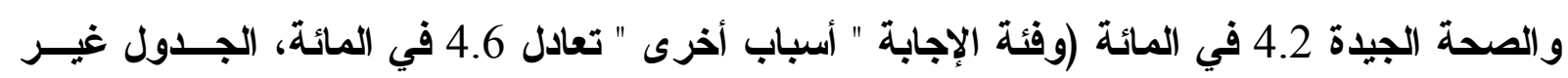
مبين). ومن بين الفتيات اللاتي صرحن بان الختان غير ضروري، هناك 33.3 في المائة قلن أنهن لا يعرفن

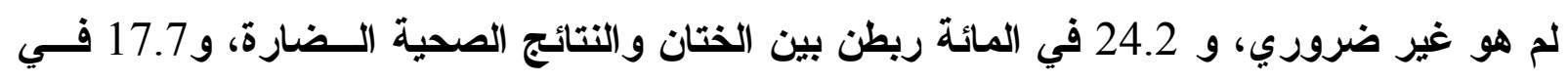

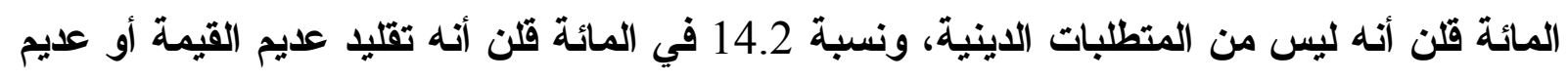

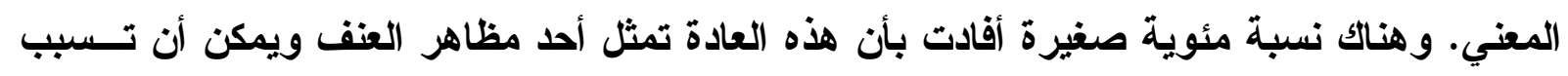

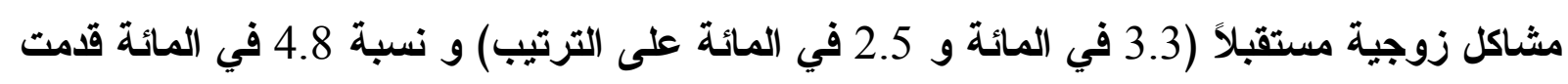

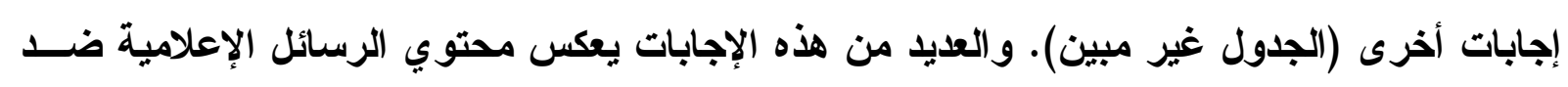

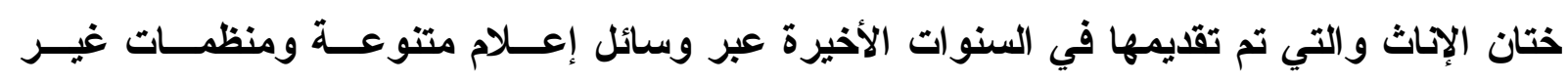

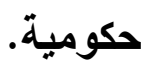
اتجاهات المراهيتات فحى سن 16 - 19 قام مسح المراهقة ASCE أيضاً بسؤال الأولاد والبنات في سن 16 - 16 - 19 (مختنات وغير مختنات)

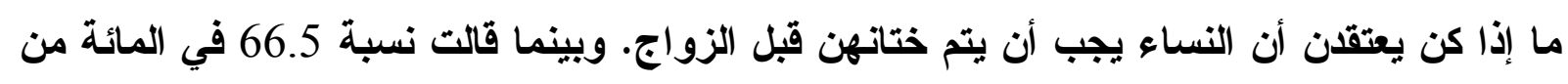

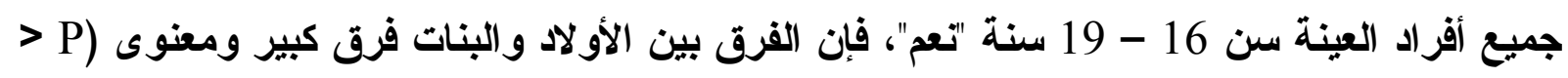

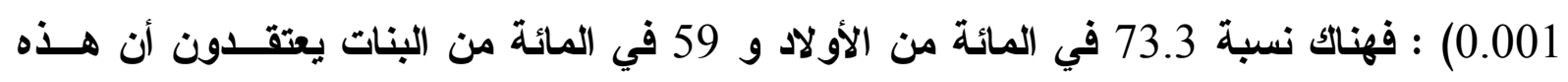

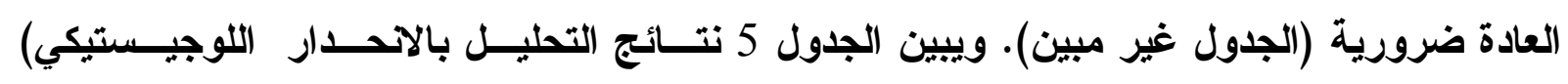

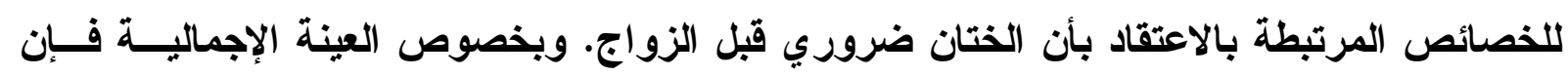

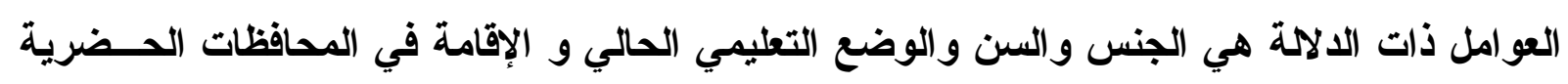

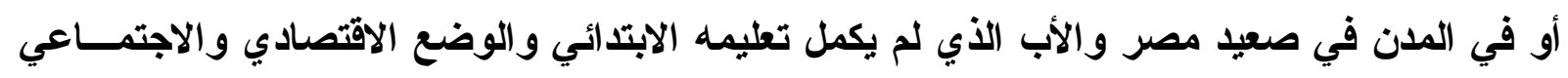

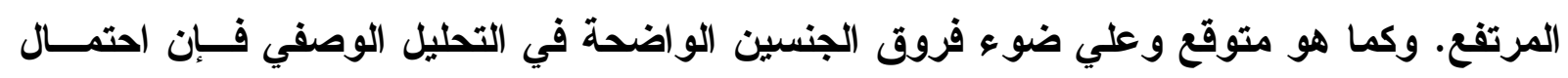
الاعتقاد بأن الختّان ضروري قبل الزواج لاي لاي الفتيات حوالى نصف الاحتمال لاي الأولاد. 
يميل الأولاد إلى التمسك بالاتجاهات الأكثر تقليدية، وقت يصبح هذا مصدراً للنزاع بين الجنسين فــي

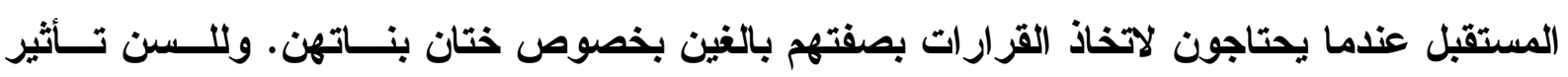

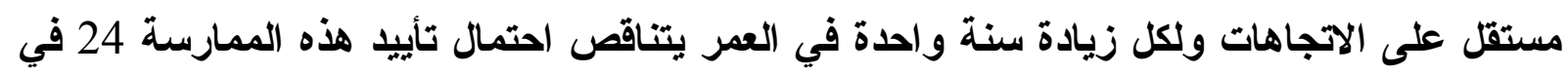

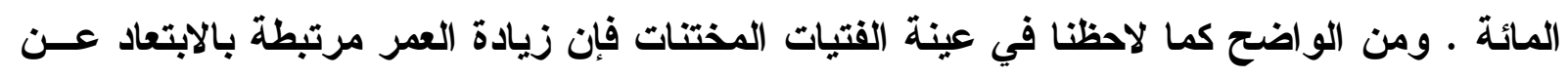
التوجهات التقليدية بخصوص الختان. واقتراب مرحلة التعارف والزواج في حياة الثباب لا يــؤدي

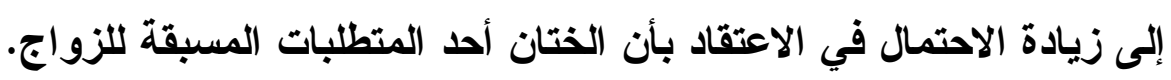

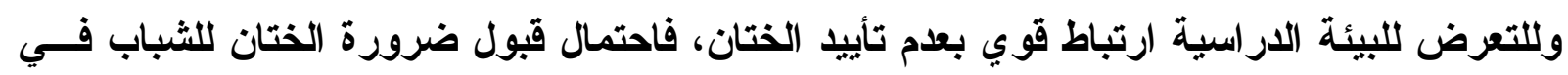

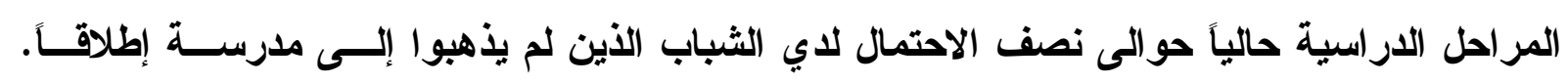

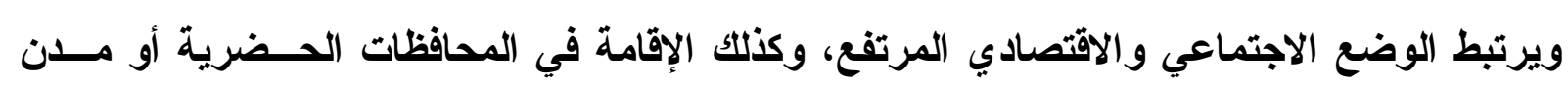

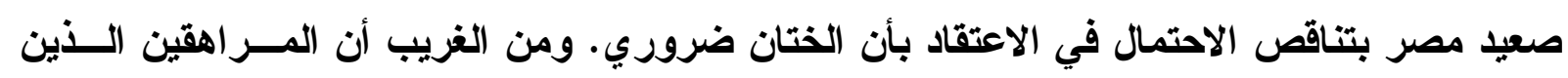

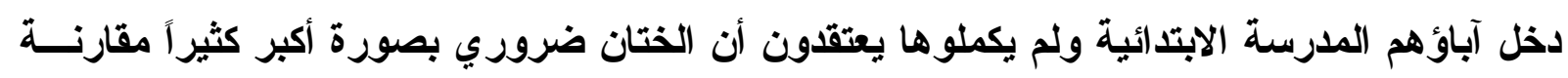
بالمراهقين الذين لم يذهب آباؤهم للمدرسة إطلاقاً.

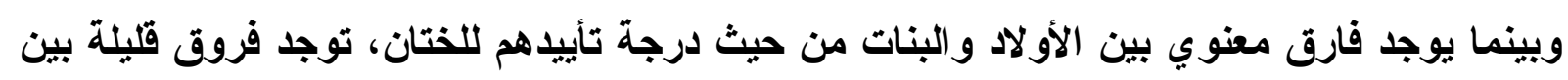

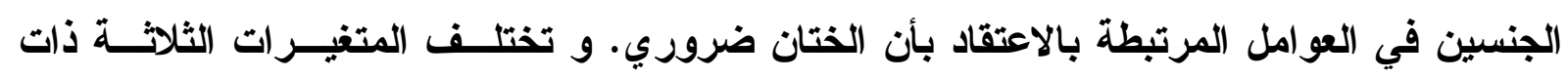

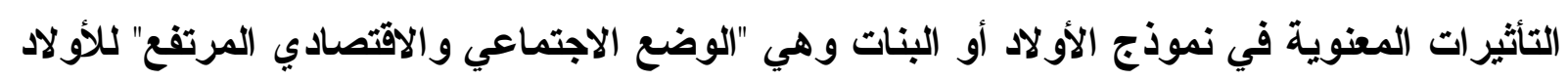

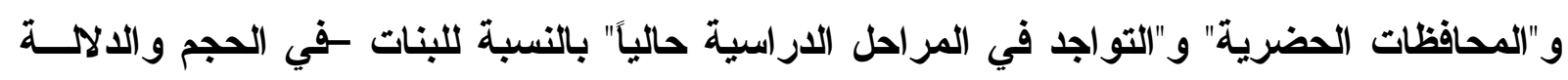
ولكنها لا تختلف في الإثارة بين النموذجين.

الملخص و الالالات الخاصة بالسباسات

تفيل البيانات من مستح المراهقة والتغير الاجتماعى فى مصر أن هناك تغيرا جوهريا قد حدث مؤخراً

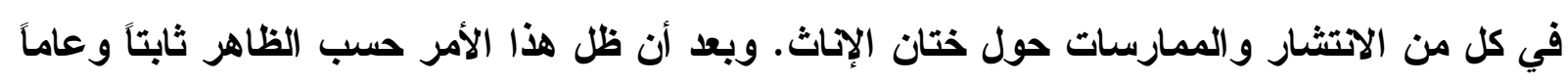

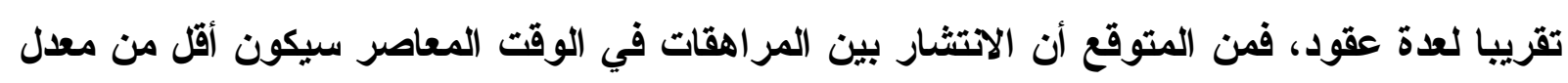

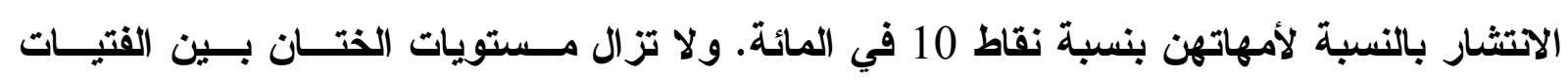

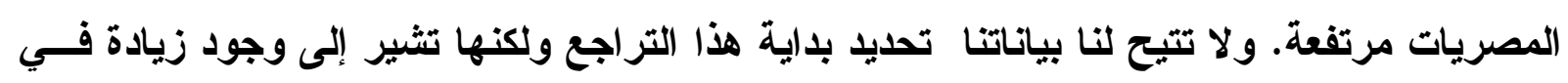

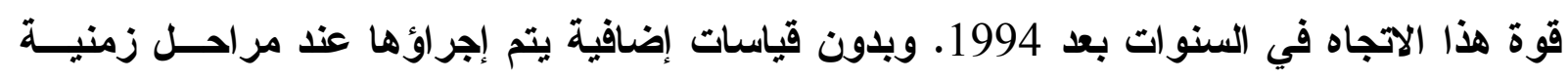
لاحقة، لا يمكنتا التأكد أن الفتيات غير المختنات في عينة مسح المراهقة ASCE ستتجنب الختــان 
مستقبلاً. ولكن تحليل الاتجاهات لدي البنات بخصوص هذه الممارسة يشير إلــى أن زيــادة العمـر تصحبها استقلالية أكبر في التفكير وتأييا أقل للختان. وتبين بيانات مسح المراهقة ASCE أن الخطر الأكبر للختان بالنسبة للبنات يبدأ في سن 8

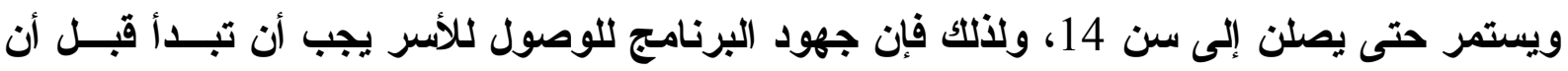
تقترب البنت من سن البلوغ وتستمر خلا السن التى تكون الفتيات عندها أكثر عرضة للخطر وهى لهى لهن

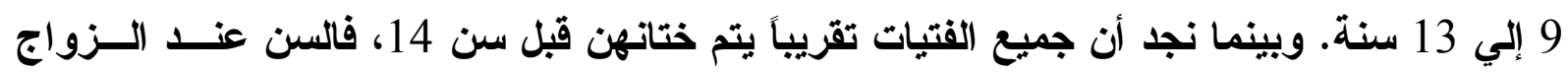

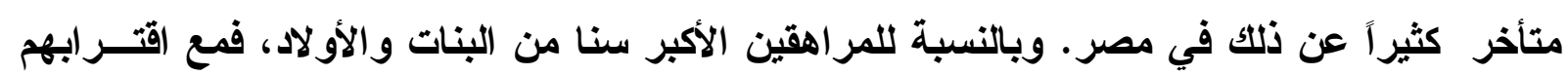

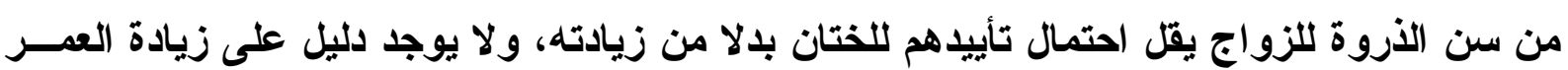

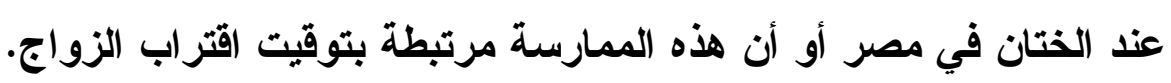
يؤثر مستوى تعليم الأم تأثير آ قوياً على احتمال ختان البنت. ولكن يجب أن تصل الأمهات ل لمستويات

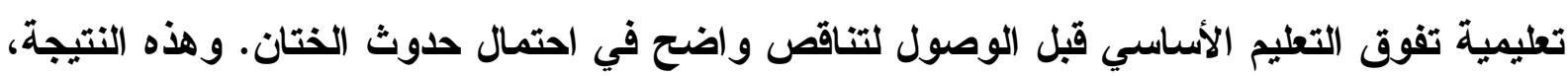

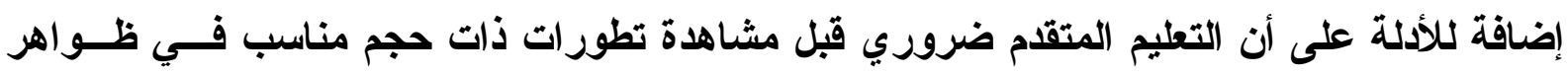

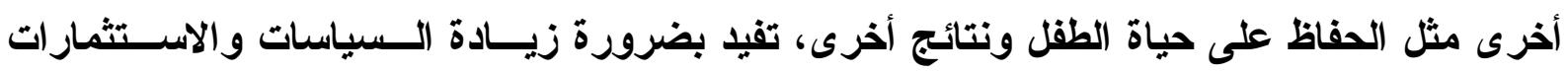
لغرض التوسع في التعليم الثانوي. وعلى وجه عاجل، يمكن الاستعانة بحملات التوعية على مستوى

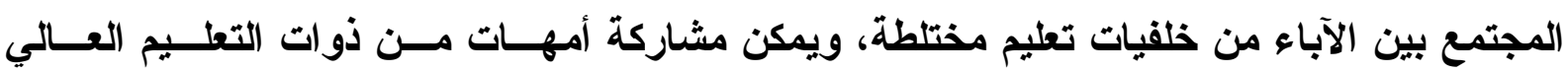
كمثقفات لنظائر هن والاستعانة بهن كنماذج ملموسة. تزيد الإقامة في صعيد مصر والإقامة في المناطق الريفية احتمالات الختان بثكل هام ، وذلك فــي حالة ثبات عوامل الخلفية الأخرى. وهذا يفيد بأن جهود التنمية الحالية المرتبطة بالبرامج الموجهة لتهية

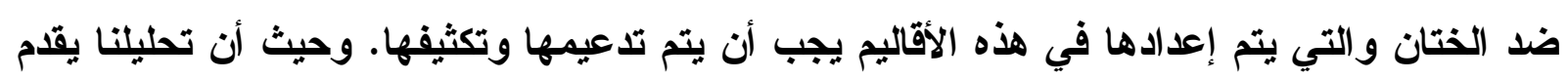

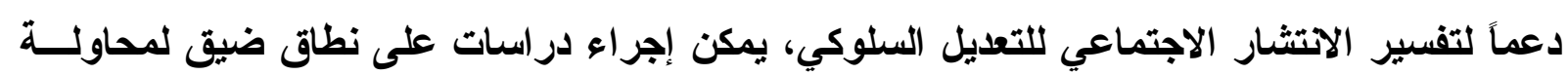

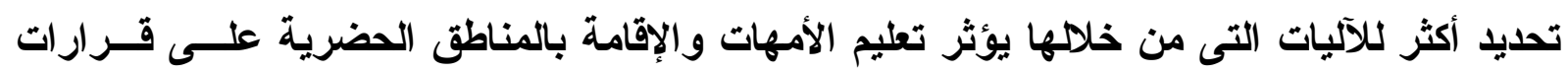
الذتان.

وبينما يوجد دليل ضعيف على أن زيادة اضفاء الطابع الطبي على ختان الإناث الملاحظة فى المسـح الايموجرافى DHS سنة 1995 تتجه نحو الثبات ، فالأطباء ماز الوا هم المقدم الرئيسي لممارسة

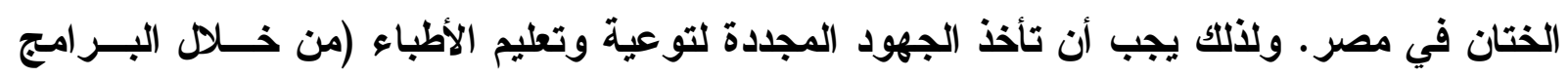


الاراسية الطية و من خلال الاجتماعات والنشرات المهنية) والإلزام بالقو انين القائمة حالياً الأولوية

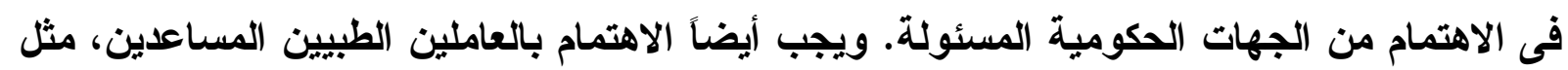
الممرضات و الدايات المدربات والأخصائيين الاجتماعيين الذين يعملون في العيادات ومراكز صـــة المجتمع.

ومع تخلي الآباء عن الممارسين التقليديين للختان، فإنهم يحاولون الحصول على هذه العمليـة فـــي

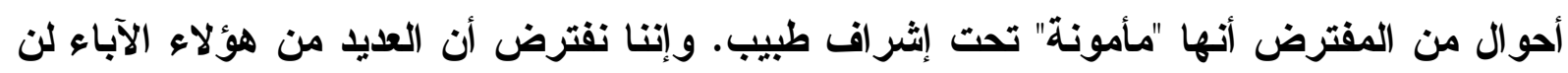

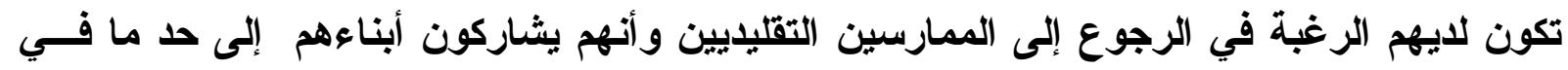

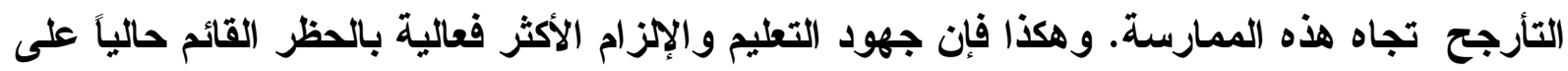
الختان بين الأطباء و الممرضات من الممكن أن تؤدى إلى عدول هذه الأسر عن الممارسة مستقبلاً.

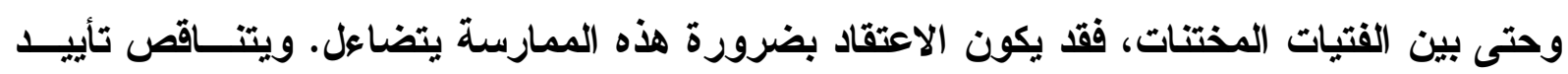

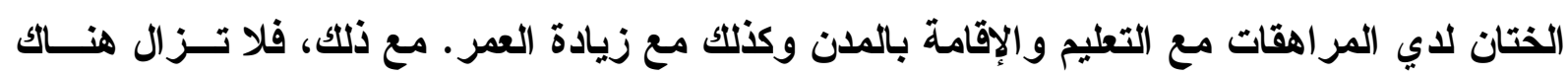
فجوة كبيرة بين الجنسين في الاتجاهات حتى مع ثبات العوامل الأخرى، حيث يؤيد الأولاد الختــان

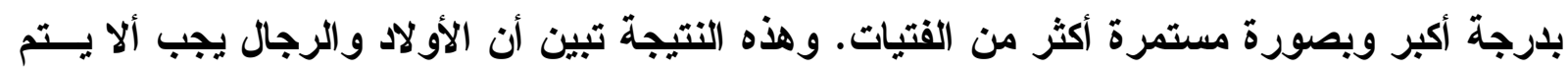
تجاهلهم في البرامج التي تتناول مسألة الختان. وعلي ضوء الأدلة المقدمة هنا والتي تبين تراجعاً مؤخراً في ختان الإناث، يلزم إجراء المزيد مسن

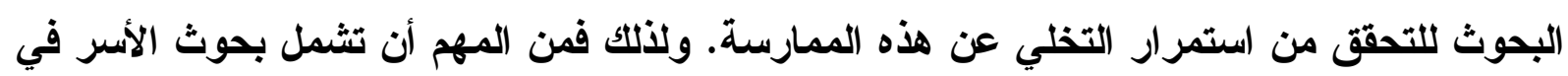
عيناتها النساء غير المتزوجات بالاضافة للمتزوجات في سن الإنجاب. و إعداد نموذج بحث إنهرة إحصائي

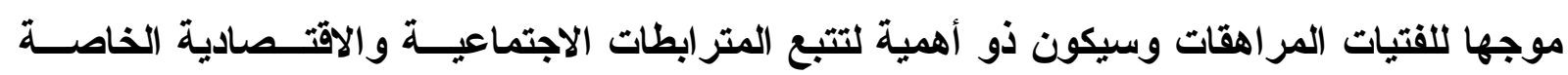

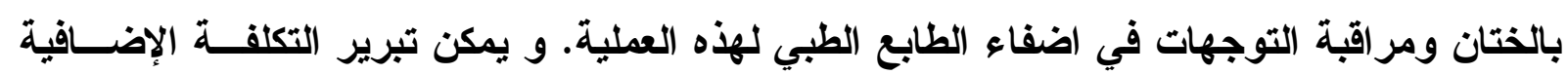
لهذه الوحدة من حلا إضافة أسئلة بخصوص الموضوعات الهامة الأخرى للصحة الإجابية والتـي لئي تؤثر على المراهقات. 
ملحق

تحديد شهر الختان

نظراً لاهتمامنا بالتغيرات الزمنية لمعدلات الختان، فمن الضروري تعيين السنة والثهر الذين حـدث

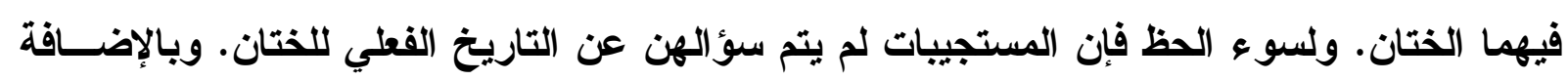
إلى ذلك على الرغم من أن جميع المستجيبات قد قمن بإعطاء عمر حالي صحيح، فهناك 346 حالـــة

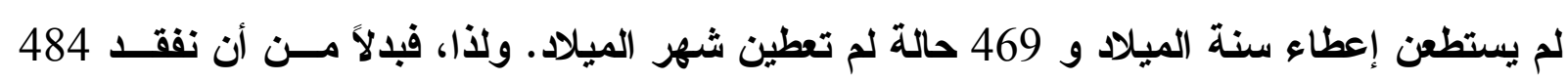

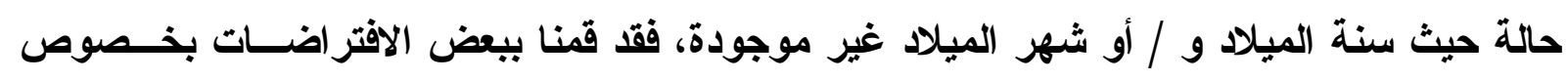

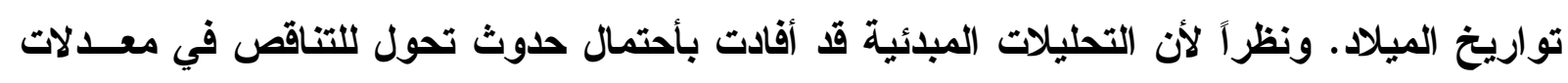

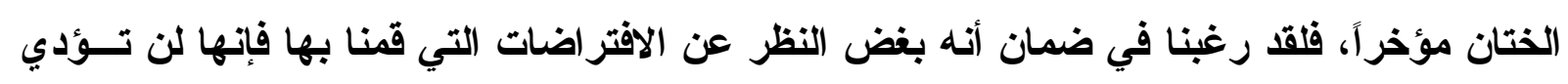
إلى زيادة هذا التأثير بصورة مصطنعة. وبوضع ذلك في اعتبارنا توصلنا للقواعد التالية:

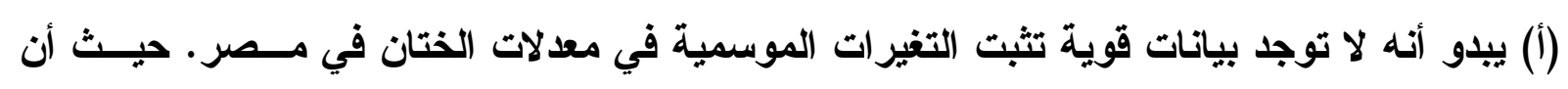

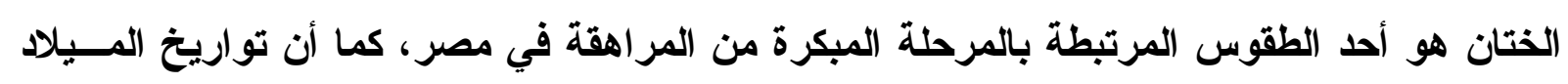

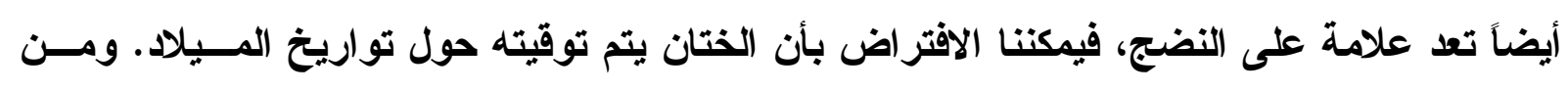
ناحية أخرى فإن هذا الافتراض قد يدفع بصورة مصطنعة توقيتات الختان إلى توقيت سابق (إذا كان

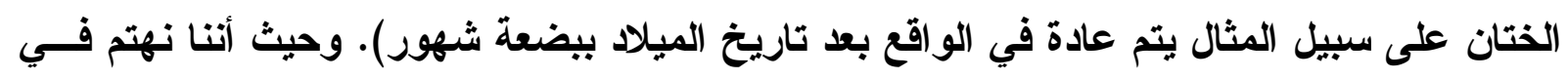

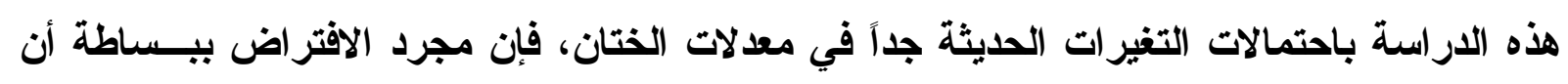

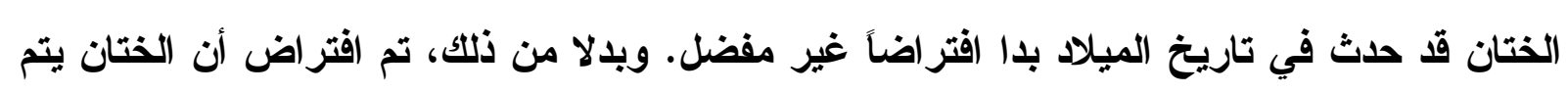

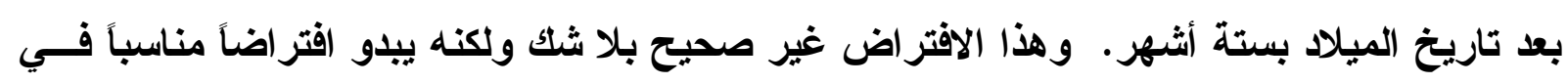

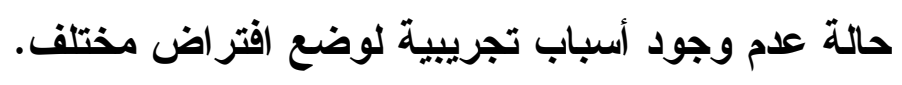

(ب) بالنسبة لعدد 15 حالة التى أعطى فيها شهر الميلاد ولم تعط سنة الميلاد، تم حساب السنة على

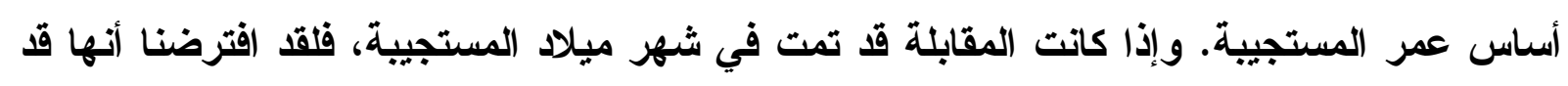
احتفلت بالفعل بعيا ميلادها.

(ج) بالنسبة لعدد 469 حالة حيث لا يوجد شهر الميلاد ، تم تعيين شهر ميلاد للمستجيبات بـصورة عشوائية على أساس التوزيع المتماثل. 
(د) بمجرد تحديد شهر ميلاد لجميع المستجيبات، تم حساب سنة الميلاد على أســاس العــر الــــى قررته المستجيبة، وتاريخ المقابلة، وشهر الميلاد المعين.

يقلم الجدول الملحق 1 التوزيع التكراري لثهور الميلاد سواء قبل أو بعد تعيين الحالات الناقـصة

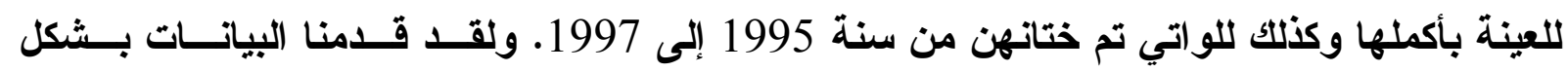

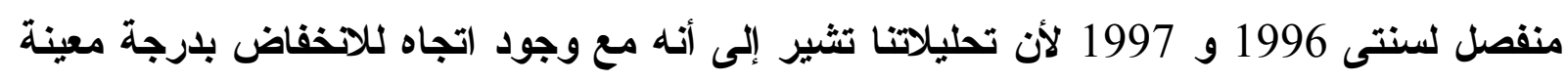

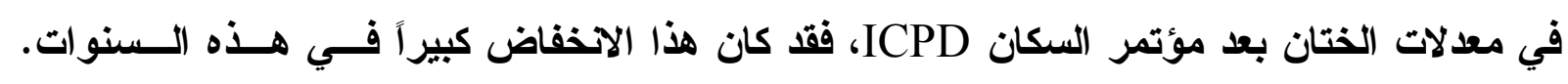

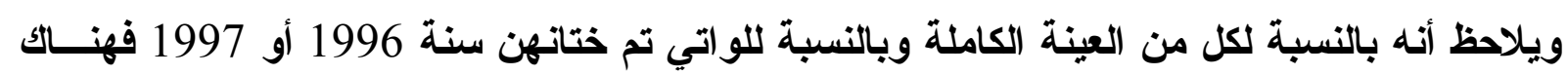

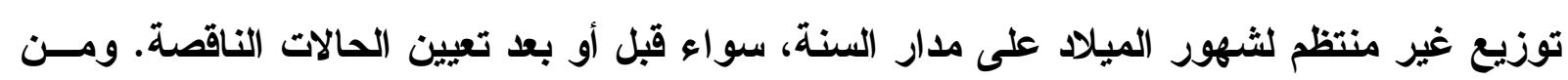

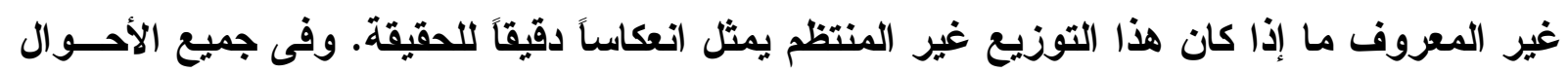

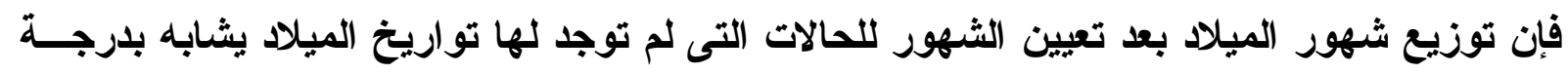
كبيرة التوزيع الذي تم فقط على أساس المستجيبات اللواتي قمن بتحديد شهر ميلاد صحيح، مما يزيل الثقة في النتائج التي تم الحصول عليها باستخدام متغير الثهر المعين.

$$
\text { الجدول الملحق } 1 \text { : التوزيع التكراري لشهور الميلاد }
$$

\begin{tabular}{|c|c|c|c|c|}
\hline \multicolumn{2}{|c|}{ الختان سنة 1996 و 1997 (أ) } & \multicolumn{2}{|c|}{ العينة الإجمالية } & \multirow[b]{2}{*}{ الثهر } \\
\hline التواريخ الناقصة (\%) & التونتبعدة (الناقصة) & التوتضمنة (اربخة & التونتبعدة (الناقصة) & \\
\hline 14.9 & 17.0 & 13.6 & 13.5 & يناير \\
\hline 9.6 & 9.4 & 8.3 & 7.2 & فبر اير \\
\hline 7.7 & 6.6 & 8.2 & 7.6 & 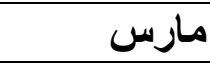 \\
\hline 9.1 & 7.5 & 9.1 & 8.3 & إبريل \\
\hline 4.8 & 4.7 & 7.0 & 6.5 & مايو \\
\hline 2.9 & 1.9 & 5.3 & 4.8 & يونيو \\
\hline 8.2 & 7.5 & 7.3 & 7.0 & يوليو \\
\hline 6.3 & 5.7 & 6.9 & 7.0 & أغسطس \\
\hline 11.1 & 13.2 & 8.9 & 10.3 & سبتمبر \\
\hline 10.6 & 10.4 & 9.8 & 10.3 & أكتوبر \\
\hline 10.6 & 12.3 & 8.5 & 9.2 & نوفمبر \\
\hline 4.3 & 3.8 & 7.3 & 8.2 & ديسمبر \\
\hline 208 & 106 & 1237 & 768 & $\mathrm{~N}$ \\
\hline
\end{tabular}

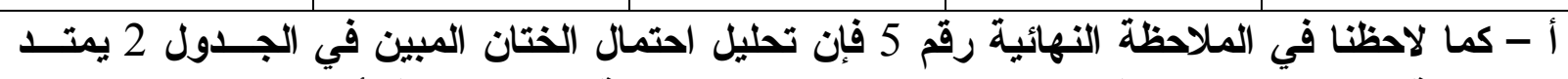
خلا سنة 1996. ولكنتا نناقش التحليلات التي تمتد خلال سنة 1997 وهئ وهذا أضفنا بيانات 1997. 
يثكر المؤلفون على المساعدة المقدمة من جون كاسترلاين الأي قدم تعليقات وتوجيهــات مفيــــ. ويشكر المؤلفون أيضاً مارك مونتجومري على الاستشارات الإحصائية؛ وسحر الطويلة مسـن مركـز الأبحاث الاجتماعية / الجامعة الأمريكية بالقاهرة التي قامست بتوجيـهـه مـسـع المر اهقـة ASCE والإجابة على الأسئلة العديلة بخصوص البيانات؛ وماري أسعد منسـث المنظمــة غيــر الحكوميــة المصرية لحملة القضاء على تثويه الأعضاء التتاسلية للإناث، والتي ساعدت في تحديد المعلومــات بخصوص موسمية الختان. ولقد تم تقديم الاعم المالي لهذا البحث من مجلس الـسكان، وصــندوق الإمم المتحدة للسكان UNFPA والوكالة الأمريكية للتنمية الدوليـة USAID (بموجـب التمويـل المقدم من الاتفاقية التعاونية لمجلس السكان رقم 14-ACP-A-00-94-000013) ومؤسسة روكفلر و الوكالة الكندية للتنمية الدولية CIDA والحكومة الهولندية والمركـز الــدولي لبحـوث التنميـة IDRC

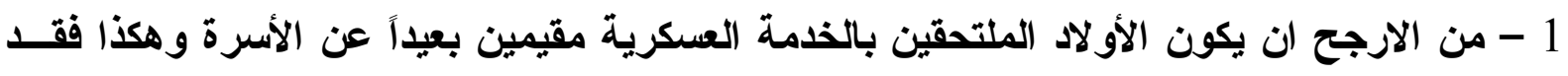
انخفض تمثيلهم في العينات. 2 - الشكل 1 محدد على أساس 847 حالة للقتيات المختنات واللواتي قدمن عمراً صــيحاً لهـــه العملية بالإضافة إلى 335 حالة لفتيات غير مختنات.

3 - يوجد أيضاً بعض الاليل على الاخفاض من المسح الايموجرافى DHS نفسه. فالنساء اللواتي تمت مقابلتهن للمسح DHS اللاتي لايهن بنات على قيد الحياة تم سؤالهن عن حالة الختان بالنسبة لبناتهن وكذلك نواياهن بالنسبة لبناتهن غير المختنات في الوقت الحالي. وبينما كاتت عينة البنـات لسن 10 - 19 لا تمثل جميع المراهقات، حيث أنها تستبعد بنات النساء الأكبر من 50 سنة، ولكـن البيانات تبين تراجعاً عن الاتتشار الكامل تقريباً في ذلك الوقت والملحوظ بين الأمهات أنفسهن. 4 - تمت موازنة كل من المكونات الثثلاثة الأولي على أساس معدلات التكرار النسبية لكل أسرة، وتم توحيد المكونين الأخيرين قياسياً بين جميع الأسر. أما المؤشر النهائي فهو يجمع المكونات الفرعية الخمسة الموحدة بنظام قياسي واحد ثم يقسمها بعد ذلك إلى ثلاث فئات متساوية. 
5 - يمتل هذا التحليل فقط خلال سنة 1996 حيث أنها السنة الكاملة الأخيرة التي تـضمنها المسـح الذي تم في منتصف سنة 1997. و إذا كانت سنة 1997 متضمنة كذلك فإن التناقص فـي معـدلات

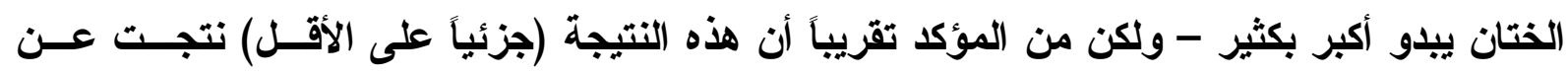
تحريف التقديرات بسبب موسمية الختان وعدم اكتمال بيانات 1997. 6 - انتثار الختان بين النساء عمر 25 - 29 سنة قد يكون بالفعل أقل من التقديرات فــي المسـح الديموجرافى DHS وذلك لأن 13 \% من هذه المجموعة لم تتزوج بعد. وميع هذا، إذا افترضــنا أن هناك نسبة ثلاثة أرباع فقط من غير المتزوجات في سن 25 - 29 مختونات، فإن النـسبة الفعليـة فيسة للمختنات ستكون 94 \% للمجموعة الكاملة للمتزوجات وغير المتزوجات فى سـن 25 - 29، وإذا افترضنا أن نسبة 90 \% من النساء غير المتزوجات مختنات فإن إجمالي النسبة سيصل إلى 96 \% وباختصار فمن المحتمل أن هناك نسبة أكبر من 90 \% مختنات لجميع النساء 25 - 29 سنة سواء

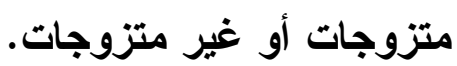
7 - العمر الوسيط عند الولادة الأولي للنساء فى سن 45 - 49 كان 20.3، ولـــلكـ فــإن العـــر الوسيط عند الحمل (أي عبر جميع الولادات) أكبر قليلاً، ربما بين 25 و 30. 8 - بيانات التعليم للنساء 65 سنة فأكبر تجميعية، وبحسب الافتر اض فإن الأرقام للنساء 75 ســنة و أكبر تبين مستوى تعليمي أقل من البيانات المجمعة للنساء 65 فأكبر. 9 - نظرا لنقص المطومات لدينا عن أمهات المستجيبات فعلينا أن نعتمد على البيانات المقدمة مـن

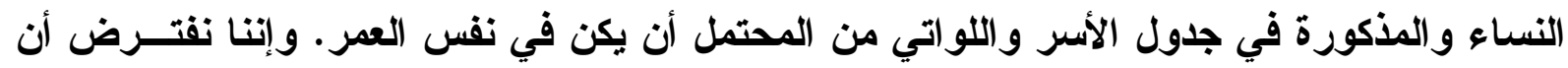
أمهات النساء اللواتي تمت مقابلتهن في المستح الايموجرافى DHS لهن مستويات تعلـيم مماثلـــة

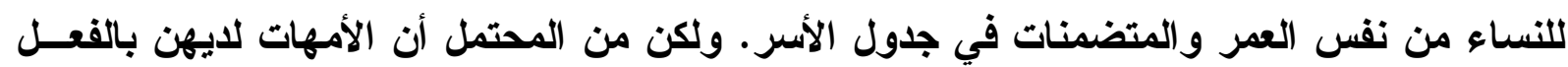

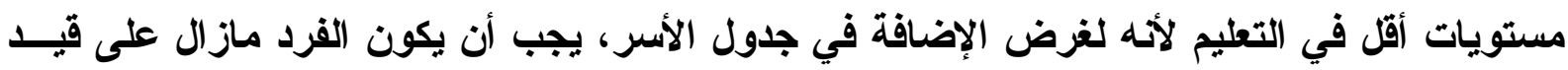

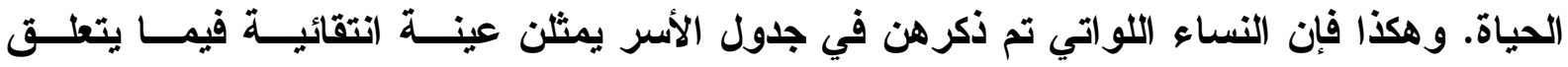

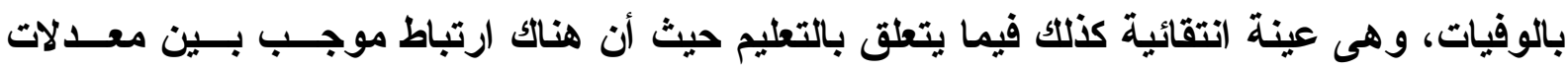
التعليم وتوقعات الحياة. ولكن لا يوجد لاينا سبب للاعتقاد بأن هذا الانتقاء الاختياري نفـسه يعــل بصورة انتقائية. أي أنه من المحتمل أن النساء فى سن 50 - 54 وسن 65 أو أكبر والمذكورات في لانيات 


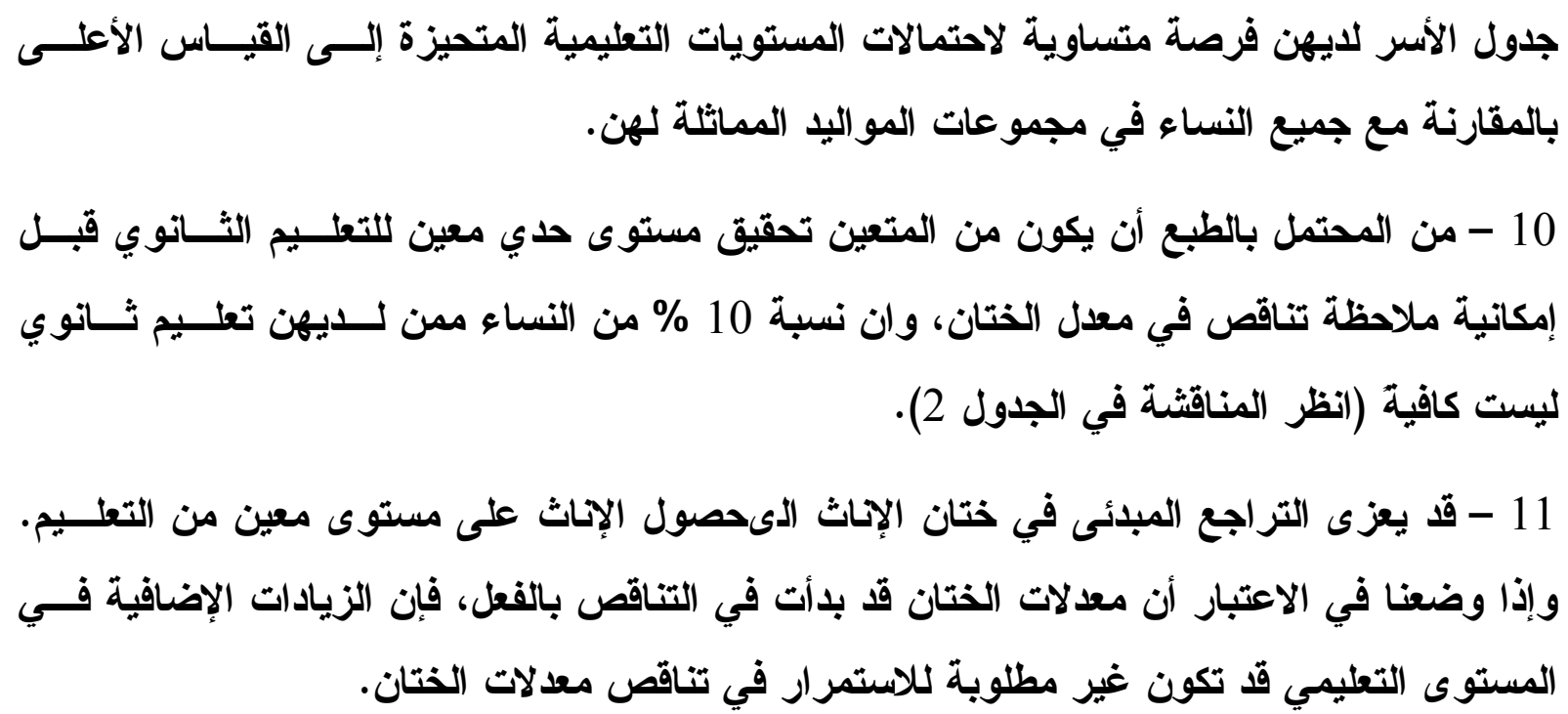

\section{References}

Assad, Marie Bassili. 1980. "Female circumcision in Egypt : Social implications, current research and prospects for change," Studies in Family Planning 11, no.1:

3-16.

El Sanabary, Nagat. 1993. "Middle East and North Africa,"in Elizabeth M.King and M.Anne Hill (eds.), Women's Education in Developing

Countries: Barriers, Benefits, and Policies. Baltimore:Johns Hopkins University Press, pp.136-174.

El Tawila, Sahar et al.1999. Transitions to Adulthood: A National Survey Of Egyptian Adolescents. Cairo Population Council.

El Zanaty, Fatma et a1.1996. Egypt Demographic and Health Survey,1995.

Calverton, MD: National Population Council of Egypt and Macro InterNational, Inc. 
Ikram, Khalid.1980.Egypt:Economic Management in a Period of Transition. Baltimore: Johns Hopkins University Press.

Jones, Heidi, Nafissatou Diop, Ian Askew, and Inoussa Kabore. 1999. "Female genital cutting and its negative health outcomes in Burkina Faso and Mali," Studies in Family Planning 30,no.3: 219-230.

Khan, Shahrukh R.1993."South Asia,"in Elizabeth M.King and M.Anne Hill (eds.),Women's Educatioon in Developing Countries: Barriers,Benefits, and Policies. Baltimore: Johns Hopkins University Press, pp. 211-246.

Montgomery, Mark R. and John B. Casterline.1996. :Social learning, social influence, and new models of fertility," Population and Development Review, Supplement to Volume 22:151-175.

National NGO Commission for Population and Development (NCPD). 1997.’FGM Task Force Position Paper." Cairo, October.

Rogers, Everett M.1962. Diffusion of Innovations. New York: Free Press Of Glencoe. Toubia, Nahid. 1995. Female Genital Mutilation: A Call For Global Action. New York: Population Council.

_ 1998. Female Genital Mutilation : An Overview. Geneva: World Health Organization.. 